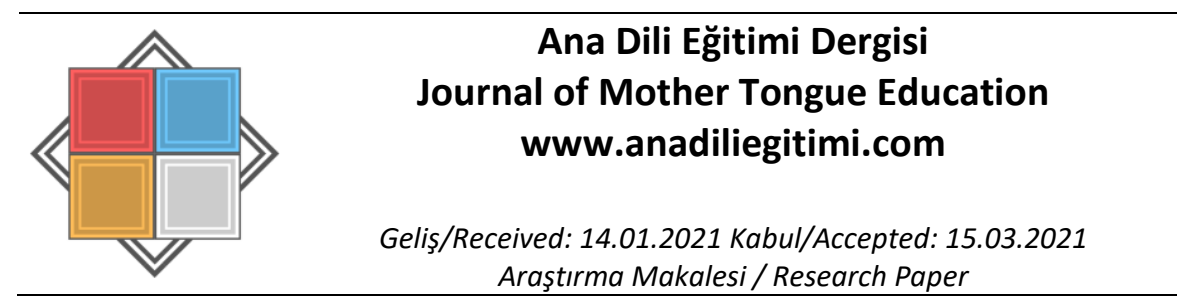

\title{
Strateji Öğretiminde Kullanılan Farklı Yaklaşımların Öğrencilerin Okuma Stratejileri Üstbilişsel Farkındalık Becerilerine Etkisi*
}

\author{
Funda AMANVERMEZ INCIRKUŞ \\ Latif BEYRELi***
}

\begin{abstract}
Öz
Çalışmanın amacı, strateji öğretiminde kullanılan farklı yaklaşımlarla öğrencilerin okuma stratejileri bilişsel farkındalık becerileri arasında nasıl bir ilişki olduğunu belirlemektir. Araştırmada 6. sınıf düzeyinde 2 deney ve 1 kontrol grubuyla çalışılmıştır. 1. grupta öğretmenin "rehber"; 2. grupta öğretmenin stratejileri açıklayarak "model" olduğu açık strateji öğretim yaklaşımları benimsenmiştir. Deney gruplarında strateji öğretiminde, bütüncül okuma stratejileri kullanılmıştır. Kontrol grubunda stratejiler öğretmen rehberliğinde örtük bir yaklaşımla ve birbirinden bağımsız olarak öğretilmiştir. Araştırmanın modeli kısmen karma sıralı baskın statülü tasarımdır. Örneklem ölçüt örneklemeyle belirlenmiştir. Deneysel süreçte 95 öğrenci, nitel süreçte 32 öğrenciyle çalışılmıştır. Uygulama 10 hafta sürmüştür. Veriler, "Okuma Stratejileri Üstbilişsel Farkındalık Envanteri (MARSI)" ve yarı yapılandırılmış görüşme formuyla toplanmıştır. Analizler SPSS 22 ve MAXQDA 12 programıyla yapılmıştır. Açık strateji öğretimi yaklaşımının ve bütüncül okuma stratejilerinin kullanıldığı, öğretmenin stratejileri açıklayarak "model" ve "rehber" olduğu deney gruplarında öğrencilerin okuma stratejileri bilişsel farkındalık becerilerinde farklılaşma olurken; stratejilerin örtük yaklaşımla öğretmen rehberliğinde ve bağımsız olarak öğretildiği kontrol grubunda farklılaşma gerçekleşmemiştir. Nitel veriler de nicel verileri desteklemektedir.
\end{abstract}

Anahtar Kelimeler: Açık öğretim, örtük öğretim, bilişsel farkındalık, okuma stratejileri

\section{The Effects of Different Approaches Used in Strategy Teaching on Students' Reading Strategies Metacognitive Awareness Skills}

\begin{abstract}
The purpose of the study was to determine the relationship between different approaches used in strategy teaching and students' reading strategies metacognitive awareness. Two experimental groups and a control group were used at the $6^{\text {th }}$ grade level in the study. In Group 1 the teacher acted as the "guide"; in Group 2 the explicit strategy teaching approach in which the teacher explained strategy use and acted as the "model" was adopted. Holistic reading strategies were used in the experimental groups. In the control group, strategies were taught under teacher guidance using an implicit approach and independently of each other. The study employed a partially mixed sequential dominant status design. Sampling was determined by criterion sampling. 95 students participated in the experimental phase of the study and 32 students participated in the qualitative phase. The implementation lasted 10 weeks. The data were collected using the "Metacognitive Awareness of Reading Strategies Inventory (MARSI)" and a semi-structured interview form. SPSS v. 22 and MAXQDA 12 software were used for data analysis. In the
\end{abstract}

\footnotetext{
* Bu çalışma Funda A. İncirkuş'un, Latif Beyreli danışmanlığında tamamladığı doktora tezinden (2018) elde edilen verilerden üretilmiştir.

** Öğr. Gör. Dr., Jandarma ve Sahil Güvenlik Akademisi, JSGA Fakültesi, Sosyal Bilimler Bölümü, Ankara, fundaamanvermez@hotmail.com, ORCID: orcid.org/0000-0002-5913-122X.

*** Prof. Dr., Marmara Üniversitesi, Atatürk Eğitim Fakültesi, Türkçe ve Sosyal Bilimler Bölümü, İstanbul, beyreli@marmara.edu.tr, ORCID: orcid.org/0000-0002-0130-3332.
} 
experimental groups in which the explicit strategy teaching approach and holistic reading strategies were used and teachers explained the strategies and modeled them or acted as the guide, a significant difference was observed in the students' reading strategies metacognitive awareness skills. No significant difference was observed in the control group in which strategies were taught with an implicit approach under the guidance of the teacher and independently of each other. The qualitative data also supported these quantitative findings.

Keywords: Explicit teaching, implicit teaching, metacognition, reading strategies

\section{Giriş}

Bilişsel farkındalık; kişinin kendi bilişsel süreci üzerine düşünme, analiz etme, sonuç çıkarma, öğrenme ve öğrendiklerini uygulamaya aktarabilme becerisini içerir (King, 1999'dan akt. Rahman ve Mahsur, 2011). Başka bir deyişle kişinin kendi düşünme, anlama veya öğrenme sürecinin farkında olarak bu süreci düzenlemesi anlamına gelir (Zimmerman ve Moylan, 2009).

Kuhn (2000), kişinin önceki öğrenmelerinden yola çıkarak yeni bilgiyi yapılandırma sürecinde hangi stratejilerin hangi durumlarda nasıl kullandığına ve bu süreci kontrol etmek etmek için hangi üst düzey stratejilerin işe koşulduğuna dair bilişsel farkındalık becerisinin geliştirilmesinin hem örgün öğretim süreci hem de yaşam boyu öğrenme açısından önemli bir hedef olduğunu belirtmektedir.

OECD'nin 21. yüzyılda eğitim sisteminden beklentisi, çağın gereklerine uygun olarak kendi düşünme sürecini yönetebilen başka bir deyişle öğrenmeyi öğrenme becerisi gelişmiş bireyler yetiştirebilmektir. Bunun için eğitimde uygulanması gereken dört boyutlu modelin bileşenleri: "bilgi, beceri, kişisel özellikler ile bu özellikleri dikkate alarak gerçekleşen üst bilişsel öğrenme"dir (Fadel vd., 2015).

Bilişsel farkındalık konusunda öncü çalışmaları bulunan Flavell, Green ve Flavell'e (1993) göre çoğu çocuk, dört yaş civarında kendi bilişsel sürecini açıklayabilmektedir ancak yapılan araştırmalar göstermiştir ki bunun gelişmesi ve derinleşmesi ergenlikten yetişkinliğe okul sürecinde gerçekleşmektedir. Birçok araştırmada bilişsel farkındalık becerilerinin öğretilebildiği ve bunların, öğrencilerin öğrenme becerilerini geliştirdiği görülmüştür (Brown ve Pressley, 1994'ten akt. Nietfeld ve Schraw, 2002; Borkowski vd. 1987'den akt. U.S. Department of Education, 2012). Bilişsel farkındalık stratejilerinin kendiliğinden değil sınıf içinde gerçekleştirilen bilinçli uygulamalarla geliştiği araştırmalarda da ifade edilmiştir (Simpson ve Nist, 2000; Pintrich, 2002). Bu bakımdan öğretmenlerin planlı sınıf içi uygulamalarla öğrencilerin bilişsel farkındalık becerilerini geliştirmeleri önem arz etmektedir. Bilişsel farkındalık becerileri kişilerin kendi düşünme ve öğrenme süreçlerini planlamalarını, düzenlemelerini ve değerlendirmelerini sağlayan stratejilerdir. Örgün öğrenim sürecinin büyük oranda okuma yoluyla gerçekleştiği düşünüldüğünde anlamanın etkin bir biçimde gerçekleşebilmesi için okuma süreciyle bilişsel farkındalığı bütünleştiren bilişsel farkındalık okuma stratejileri öğretmenlere yol gösterici olmaktadır. Okuma sürecinde kullanılan bilişsel farkındalık okuma stratejileri genel olarak: okuma amacı belirleme, önceki bilgilerden yararlanma, metinler arası ilişki kurma, metnin biçimsel özelliklerine dikkat etme, okunanlar üzerine düşünme, metinle ilgili soru sorma-cevaplama, metni anlayıp anlamadığını sorgulama, metni izleme, not alma, tekrar okuma, özetleme, bilinmeyen kelimelerin anlamını bulma, metni çeşitli yönlerden değerlendirme, öğrendiklerini transfer etme, metni anlama sürecinde kullandığı stratejilerin uygun olup olmadığını kontrol etme vb. olarak belirlenebilir.

Okuma stratejileri bilişsel farkındalıkla birlikte okuyucuların mevcut bilişsel bilgilerini metindeki önemli noktalarda kullanmalarına imkân sağlamaktadır. Aynı zamanda bu becerileri kullanmak, okunan metnin tutarlı ve mantıklı bir şekilde yorumlanmasına katkı sağlar. Okuma stratejileri ve bilişsel farkındalık becerileri öğrenilebilir ve çok geniş bağlamda kullanılabilir olduğu için okuma öğretimi başta olmak üzere çeşitli eğitsel programların bu becerileri merkeze aldığı bilinmektedir (Van der Broek ve Kremer, 2000). Bu stratejilerin öğretilmesinde ise farklı öğretim yaklaşımlarının benimsendiği görülmektedir.

Öğretmenler sınıf içi uygulamalarda öğrencilerin bilişsel farkındalık stratejilerini geliştirmek için genellikle "örtük (implicit)" ve "açık (explicit)" olmak üzere iki yaklaşım kullanmaktadır. Örtük yaklaşım (implicit), bütüncül okuma öğretimi programlarında benimsenmiştir. Yapılandırıcı yaklaşımın 
benimsendiği örtük öğretimde öğrencilerin kavramları kendi zihinsel etkileşimleri ve eylemleriyle geliştirdiği düşünülmektedir. Bu yaklaşıma göre öğrenciler kavramları tümevarım şeklinde biçimlendiren aktif bireylerdir. Okuduklarını ve duyduklarını parçalar hâlinde değil kendi bağlamında bir bütün hâlinde ele alarak değerlendirirler ve kendileri için uygun olan öğrenme yolunu belirlerler (Schreiber, 2005). Açıklamalı (explicitly) strateji öğretimi ise belirli becerileri öğretmeye yönelik programlarda benimsenmiştir. Bu yaklaşım öğretmene öğretilmek istenen okuma stratejisiyle ilgili açıklama yapma, model olma ve geri bildirimde bulunma fırsatı verir (Schreiber, 2005; Afflerbach vd., 2008).

Rosenshine (1987) bilişsel farkındalık stratejilerinin öğretilmesinde açık strateji öğretim yaklaşımının benimsenmesi gerektiğini, bu yöntemin tüm öğrencilerin derse aktif ve başarılı bir şekilde katılımının sağlanması bakımından önemli olduğunu belirtmiştir. Açık öğretim, akademik becerilerin öğretilmesini sağlayan yapılandırımış, sistematik ve etkili bir öğretim yöntemidir. Açık (explicit) olarak adlandırımasının sebebi öğretimle birlikte öğretimin gerektirdiği davranışların doğrudan açıklanmasından kaynaklanmaktadır (Archer ve Huges, 2011). Bu yöntem genel olarak (Rosenshine, 1987):

a. Öğretmenin model olduğu açıklamalı öğretim,

b. Rehberli uygulamalar,

c. Bağımsız uygulamalar olmak üzere üç şekilde gerçekleşir.

a. Öğretmenin model olduğu açıklamalı öğretim: Bu yöntemde öğretmenler iyi okuyucuların okuma sürecinde sergiledikleri zihinsel süreçleri öğrencilere açıklar. Bu süreçte kullanılan en önemli yöntemlerden biri okuma sırasında belli yerlerde durup sesli düşünerek düşünme şeklini öğrencilere göstermek suretiyle onlar için doğru bir model olmaktır. Böylece öğrenciler öğretmeni gözlemleyerek hangi durumda hangi stratejiyi nasıl kullandığını görürler. Sesli düşünme sayesinde okuma sırasında öğretmen farklı stratejileri uygulayarak stratejiler arası geçiş yapar, bu da öğretmene önceki öğrenmelerden faydalandığı sonraki öğrenmelere basamak oluşturduğu esnek bir strateji öğretimi imkânı sağlar (Nokes ve Dole, 2004). Örneğin öğretmen sınıfta bir problemi çözerken problemi nasıl çözdüğüne ilişkin bilişsel süreçlerini sınıfta sesli düşünerek ya da problemin çözümü için seçtiği belli bir stratejiyi neden kullandığını tartışarak onlara model olur. Dolayısıyla öğrenciler somut bir problemle karşılaştıklarında neyi nasıl yapacaklarına dair fikir sahibi olurlar. Böylece bilgi; tartışma, model olma ya da açık öğretim yoluyla paylaşılır ve öğrencilerin öğrenmesi de kolaylaşır (Pintrich, 2002).

Yapılan araştırmalar da model olmanın tek başına değil bilişsel farkındalığı destekleyecek uygun bilişsel stratejilerin açıklamalı bir şekilde kullanılmasıyla etkili olacağını göstermiştir. Model olma öğretmen tarafından uygulanabileceği gibi akranlar tarafından da yapılabilir. Bu sayede akran öğretici konumunda model olur dolayısıyla öğrenci arkadaşının/akranının problemi hangi yönleriyle ele aldığını, sorunu çözmek için nelere başvurduğunu gözlemleme imkânı bulur. Problemin çözümüyle ilgili fikir yürütebilir veya var olan fikrini değiştirebilir/geliştirebilir. Bu durum öğrencilerin sınıf içi etkileşimini de geliştirir (Lin, 2001).

b. Rehberli Uygulamalar: Rehberli uygulamalar öğrencilere öğretmenin gözetimi altında uygulanan stratejileri tekrar etme imkânı sağlar. Rehberli uygulamalar esnasında öğretmen öğrencileri (a) stratejiyi uygulama konusunda desteklemeli, zorlandıkları yerde yönlendirmeli ve gerektiği yerde uygun bir model olabilmeli, (b) yönlendirmelerini ve stratejinin uygulanmasına yönelik beklediği başarı kriterlerini öğrencilerin seviyesine göre ayarlamalı, (c) uygun yerlerde uygun strateji adımlarından bahsetmeli, (d) öğrencilerden stratejiyi anlatmalarını istemeli, (e) kısa süreli çalışmalar yerine farklı uzunlukta metinler ve açıklamaların yer aldığı materyaller kullanarak öğrencilerin uygulama yapmasına imkân vermelidir (Collins, 1995'ten akt. Fauzan, 2003).

c. Bağımsız Uygulamalar: Bağımsız uygulamalar öğretmenin yardımı olmadan öğrencilerin stratejiyi uygulamasına imkân tanır. Bu tarz bir çalışma ev ödevlerinde veya sınıf içi yapılan (örneğin tek olarak bir metni okuma, bir problemi çözme gibi) bireysel çalışmalarda uygulanabilir. Birçok araştırmacı öğrencilerin bir stratejiyi özümseyip öğrendiği bilgileri yeni öğrenme durumlarında uygulayabilmesi için bağımsız uygulamaların gerekli olduğunu ifade etmektedir (Baker ve Brown, 1984; Pressley, 2002). Böylelikle öğrenciler stratejiyi anlayıp anlamadıklarını ya da kullanıp kullanamadıklarını görmüş olurlar. Bağımsız uygulamalardaki en önemli nokta öğrenilen stratejiyi yeni bir göreve/duruma 
aktarabilmektir. Etkili ve doğru bir şekilde yapılan bağımsız uygulamalar stratejiyi başka bir göreve/duruma transfer etme şansını da yükseltmektedir (Baker, 1994'ten akt. Nokes ve Dole, 2004).

Araştırmacılar okuma stratejileri öğretiminde stratejilerin birbirinden bağımsız genel beceriler olarak öğretilmesindense belli bir içerik bağlamında bilişsel farkındalığı ve kendi kendini düzenleme becerilerini işleten bütüncül stratejilerin kullanılmasının daha etkili olabileceğini belirtmiştir (Hattie vd., 1996; Carter, 2011). Bütüncül okuma stratejileri, belirli bir okuma görevine yönelik okuma öncesi, sırası ve sonrasında kullanılması gereken stratejileri birbiriyle bağlantılı şekilde sunan stratejilerdir. Bütüncül okuma stratejilerinin uygulama adımları bilişsel farkındalığı yapılandırırken okuma sürecinde öğretmen-öğrenci, öğrenci-öğrenci görev ve rollerini de şekillendirmektedir. Stratejiler kullanılırken metin türü, öğrencinin ilgisi, bilişsel hazırbulunuşluğu dikkate alınmalıdır. Etkin bir strateji öğretiminin gerçekleşebilmesi için öğrencilerin bilişsel ve gelişimsel özelliklerini dikkate alan strateji öğretim yaklaşımlarının bilinçli seçimlerle gerçekleşmesi gerekir. Stratejilerin nasıl kullanılacağını bilmeyen bir öğrenci grubuna stratejileri direkt ve bağımsız olarak uygulamalarını gerektiren bütüncül bir stratejinin kullanılması öğrencilerde beklenen etkiyi yaratmayacaktır ve stratejinin etkinliğinin yanlış değerlendirilmesine sebep olacaktır. Bu bakımdan bilişsel farkındalık okuma becerilerinin geliştirilmesinde çeşitli stratejiler uygulanırken öğretmen ve öğrenci rollerini belirleyen, öğrencilerin hazırbulunuşluklarını, strateji farkındalıklarını dikkate alan ve/veya literatürde etkili olduğu öne sürülen stratejilerin öğretiminin hangi yaklaşımlarla gerçekleşmesi gerektiği önemlidir.

Bu çalışma, farklı öğretim yaklaşımlarıyla öğrencilerin okuma stratejileri bilişsel farkındalık becerileri arasında nasıl bir ilişki olduğunu tespit etmeyi amaçlamaktadır. Bu doğrultuda deney gruplarında öğretim yapılırken 1. deney grubunda öğretmenin "rehber" olduğu, 2. deney grubunda öğretmenin stratejileri açıklayarak "model" olduğu iki ayrı strateji öğretim yaklaşımı benimsenmiştir. Ayrıca deney gruplarında strateji öğretimi bütüncül okuma stratejileri kullanılarak gerçekleştirilmiştir. Bu bağlamda, öğretmenin rehber olduğu 1. deney grubunda SQ4R okuma stratejisi kullanılmıştır. SQ4R stratejisi (Pauk, 1984), bir çalışma-okuma strateji olarak bilinen SQ3R stratejisinin bir adım daha geliştirilmiş hâlidir (Caverly, 2000). Öğrenciyi aktif kılan SQ4R stratejisi okuma öncesinde inceleme, soru sorma; okuma sırasında okuma, anlatma, not alma ve okuma sonrasında değerlendirme adımlarından oluşmaktadır (Coon ve Mitterer, 2011). Öğretmenin stratejileri açıklayarak model olduğu 2. deney grubunda ise Etkileşimli Sesli Okuma (ESO) stratejisi kullanılmıştır. ESO stratejisinde öğretmen okuma sürecinde belli bir amaç doğrultusunda okuma yapar. Öğretmek istediği stratejileri, gerekli yerlerde niçin kullandığını öğrencilere sesli düşünerek açıklar ve stratejiyi nasıl kullandığını öğrencilere model olarak gösterir (Fountas ve Pinnell, 2006). ESO okuma öncesinde seçme ve hazırlanma, derse giriş; okuma sırasında metni sesli okuma, metni tartışma (gömülü öğretim) ve kendini değerlendirme; okuma sonrasında metni tartışma, okunanların kaydedilmesi, yazma ve canlandırma adımlarından oluşmaktadır. Kontrol grubunda ise stratejiler öğretmen rehberliğinde, bağımsız olarak ve örtük bir yaklaşımla öğretilmiştir. Çalışmanın alt problemleri şöyledir:

1. Okuma stratejileri öğretiminin yapıldığı deney1, deney2 grubundaki öğrencilerle kontrol grubundaki öğrencilerin okuma stratejileri bilişsel farkındalık düzeyleri arasında anlamlı bir fark var mıdır?

2. Uygulamaya katılan deney1 ve deney2 grubundaki öğrencilerin genel okuma stratejilerine ilişkin görüşleri nelerdir?

3. Uygulamaya katılan deney1 ve deney2 grubundaki öğrencilerin problem çözme stratejilerine ilişkin görüşleri nelerdir?

4. Uygulamaya katılan deney1 ve deney2 grubundaki öğrencilerin okuma stratejilerini destekleme stratejilerine ilişkin görüşleri nelerdir?

\section{Araştırmanın Modeli}

\section{Yöntem}

Yöntem olarak karma araştırma modellerinden "kısmen karma sıralı baskın statülü tasarım" kullanılmıştır (Leech ve Onwuegbuzie, 2009). Bu yöntemle nicel verilerin nitel verilerle desteklenerek daha iyi açıklanması amaçlanmıştır (Yıldırım ve Şimşek, 2013). 10 haftalık deneysel sürecin ardından öğrencilerin okuma stratejileri bilişsel farkındalık düzeylerine ilişkin nicel verileri 
açıklamak/desteklemek üzere nitel verilerden yararlanılmıştır. Çalışmanın nicel ve nitel aşamaları şöyledir:

Nicel Süreç: Çalışmada kolay ulaşılabilir örnekleme ile uygulamanın yapılacağı okul belirlenmiş ve belirlenen okul ortamındaki sınıflar kullanıldığı için "eşitlenmemiş ön test - son test kontrol gruplu yarı deneysel model" kullanılmıştır. Grupları eşitlemenin güç olduğu uygulama gruplarında bu model kullanılır. Ancak grup seviyelerinin benzer olması için önceden belirlenen ölçütlere göre ön-testlerden yararlanılır. Karşılaştırılabilir gruplar elde edilerek benzer seviyelerdeki gruplarla çalışabilmek için ön test uygulanmıştır (Cuttler, 2017). Deney grupları elde edilen sonuçlara göre rastgele belirlenmiştir (Karasar, 2012). Modelin simgesel görünümü tablo 1'de gösterilmiştir:

Tablo 1.

Modelin Simgesel Görünümü

\begin{tabular}{llll}
\hline Gruplar & Ön Test & Deneysel işlem & Son Test \\
\hline G1 & $\mathrm{O}_{1.1}$ & $\mathrm{X}_{1}$ & $\mathrm{O}_{1.2}$ \\
G2 & $\mathrm{O}_{1.3}$ & $\mathrm{X}_{2}$ & $\mathrm{O}_{1.4}$ \\
G3 & $\mathrm{O}_{1.5}$ & & $\mathrm{O}_{1.6}$ \\
\hline
\end{tabular}

G1: Deney1 grubu, G2: Deney2 grubu, G3: Kontrol grubudur.

$\mathrm{X}_{1}$ : Öğretmenin "rehber" olduğu, açık strateji öğretimi yaklaşımının benimsendiği ve SQ4R bütüncül okuma stratejisinin kullanıldığı deneysel işlem,

$\mathrm{X}_{2}$ : Öğretmenin "model" olduğu, açık strateji öğretimi yaklaşımının benimsendiği ve ESO bütüncül okuma stratejisinin kullanıldığı deneysel işlemdir. Bütün gruplarda:

$\mathrm{O}_{1.1}, \mathrm{O}_{1.3}, \mathrm{O}_{1.5}$ : Okuma Stratejileri Üst bilişsel Farkındalık Envanteri (MARSI) ön-test puanlarını

$\mathrm{O}_{1.2}, \mathrm{O}_{1.4}, \mathrm{O}_{1.6}$ : Okuma Stratejileri Üst bilişsel Farkındalık Envanteri (MARSI) son-test puanlarını ifade etmektedir.

Nitel Süreç: Nicel sonuçları daha ayrıntılı açıklamak ve uygulamaya katılan öğrencilerin sürece yönelik deneyimlerini ayrıntılı çözümlemek için "durum çalışması"na başvurulmuştur (Yıldırım ve Şimşek, 2013).

\section{Çalışma grubu}

Örneklem seçiminde "sıralı karma yöntem örneklemi"ne başvurulmuştur. Böylelikle nitel süreçteki örneklem seçimi nicel süreçteki örneklem içerisinden belirlenmiştir (Teddli ve Yu, 2007).

Nicel Süreç Çalışma Grubu: Deneysel süreçte örneklem seçimi iki adımda gerçekleşmiştir. Öncelikle kolay ulaşılabilir örnekleme ile uygulamanın yapılacağı okul belirlenmiş. Sonrasında ölçüt örnekleme ile deney ve kontrol grupları belirlenmiştir (Yıldırım ve Şimşek, 2013). Belirlenen okuldaki 5 adet 6. sınıf şubesine ön test olarak "Okuma Stratejileri Üstbilişsel Farkındalık Envanteri" uygulanmıştır. ANOVA analizi sonucuna göre aralarında fark olduğu görülen $(p<.05) 5$ sınıfın ön test sonuçlarına LSD analizi yapılmış ve aralarında fark olmadığı görülen 3 sınıftan ikisi deney, biri kontrol grubu olarak rastgele belirlenmiştir.

Tablo 2.

Deney ve Kontrol Gruplarını Belirlemeye Yönelik Ölçümlere Illişkin LSD Analizi Sonuçları

\begin{tabular}{|c|c|c|c|c|c|}
\hline Bağımlı Değişken & & & Ortalamalar Farkı (I-J) & se & $\mathrm{p}$ \\
\hline \multirow{4}{*}{$\begin{array}{l}\text { Bilişsel } \\
\text { toplamı }\end{array}$} & \multirow[t]{4}{*}{1} & 2 & $-0,496^{*}$ & 0,144 & 001, \\
\hline & & 3 & $0,379^{*}$ & 0,139 & ,007 \\
\hline & & 4 & $-0,088$ & 0,139 &, 528 \\
\hline & & 5 & $-0,155$ & 0,144 & ,286 \\
\hline
\end{tabular}


Tablo 2'de görüldüğü üzere 1,4 ve 5 . şubeler arasında "Okuma Stratejileri Üstbilişsel Farkındalık Envanteri" düzeyleri toplam puanları ön test sonuçlarında farklılık olmadığı $(p>0.05)$ görülmüştür.

Çalışma grubunda yer alacak katılımcıların sayı ve cinsiyet bilgileri şöyledir:

Deney1 grubunda 19 erkek, 13 kız toplam 32 öğrenci; Deney2 grubunda 16 erkek 17 kız toplam 33 öğrenci; kontrol grubunda 12 erkek 18 kız toplam 30 öğrenci yer almıştır.

Nitel Süreç: Amaçlı örneklem seçimiyle deneysel sürece dâhil olan öğrenciler örnekleme alınmış böylelikle nicel süreçte elde edilen sonuçlar daha iyi açıklanmaya çalışılmıştır. Her bir deney grubunda uygulamalara kesintisiz olarak katılan öğrencilerle (Deney1=16, Deney2=16) yapılan görüşmeler veri olarak kullanılmıştır.

\section{Veri Toplama Aracı}

Nicel Süreç: Veriler Mokhtari ve Reichard (2002) tarafından geliştirilen Türkçe geçerlik ve güvenirlik çalışması (Öztürk, 2012) yapılmış olan “Okuma Stratejileri Üstbilişsel Farkındalık Envanteri (MARSI)" aracılığıyla toplanmışır. Ölçek 30 madde ve 3 faktörden oluşmaktadır. Ölçeğin Türkçe geçerlik güvenirlik çalışması 5. sınıf öğrencileriyle yapılmıştır (Öztürk, 2012). Ölçeğin Türkçe formunda 'genel okuma stratejileri' faktörü .92, 'problem çözme stratejileri' faktörü .79 ve 'okuma stratejilerini destekleme' faktörü 87 güvenirlilik değerlerine sahiptir. Bu maddeler bir kişinin okuma öncesi, sırası ve sonrasında kullandığı planlama, izleme ve değerlendirme yani bilişsel farkındalık stratejileridir. Ölçek geliştirme çalışmasına katılan öğrencilerle (5. Sınıf) çalışmada yer alan öğrenciler (6. sınıf) yaş grubu bakımından birbirine benzerdir. Tüm bu özellikleri incelendiğinde ölçeğin mevcut çalışmanın amacına uygun olduğu görülmüş ve ölçeği kullanmak için araştırmacıdan izin alınmıştır.

Nitel Süreç: Veriler "yarı yapılandırılmış görüşme formu"yla toplanmıştır. Yarı yapılandırılmış görüşme formu aracılığıyla yapılan görüşmelerde katılımcı görüşme sorularını cevaplarken esnek olabildiği için araştırmacı da konu hakkında daha detaylı bilgiye sahip olabilmektedir (Barbour ve Schostak, 2005). Bu doğrultuda öğrencilere okuma öncesinde, sırasında ve sonrasında zorlandıkları durumlarda hangi stratejilere başvurdukları sorulmuştur. Form oluşturulurken araştırmacı tarafından uygulama odaklı görüşme soruları hazırlanmış ve 4 uzmanın görüşüne sunulmuştur. Formun değerlendirme düzeyi en düşük 1 , en yüksek 5 olmak üzere 1-5 arası derecelendirilmiştir. Bütün uzmanlar tarafından 4 ve üzerinde derecelendirilen maddeler görüşme formuna alınmıştır. Uzman görüşleri sonrasında 5 öğrenciyle pilot uygulama yapılmış ve tekrar 2 uzman görüşü alınarak forma nihai şekli verilmiştir.

\section{Verilerin Toplanması}

Nicel Süreç: Veriler, uygulama öncesinde ve sonrasında belirlenen deney ve kontrol gruplarından toplanmıştır. Deneysel uygulama 10 hafta sürmüştür. Uygulama dersleri haftada 3 saat olmak üzere araştırmacı tarafından yürütülmüş, kontrol grubunda mevcut müfredata göre eğitim yapılmıştır. Deney gruplarında uygulama yapılırken okuma stratejileri bilişsel farkındalık stratejileri Deney1 grubunda SQ4R okuma stratejisinin okuma öncesi, sırası ve sonrası adımlarıyla bütünleştirilerek öğretilmiş; Deney2 grubunda ise Etkileşimli Sesli Okuma (ESO) stratejisinin okuma süreci adımlarıyla bütünleştirilmiştir. Deney1 grubunda okuma öncesinde amaç belirleme, tahmin etme, görselden yararlanma, metnin biçimsel özelliklerine bakma, soru sorma; okuma sırasında not alma, anladıklarını kendi cümleleriyle ifade etme, tekrar okuma, yavaş okuma, sesli okuma, kaynaktan yararlanma, işaretleme, altını çizme, belli bir yere kadar okuyup düşünme, okuduklarını tartışma, metindeki ipuçlarından yararlanarak anlamı bulma, tahmin etme, düşünceler arası ilişki kurma, dikkat verme; okuma sonrasında ise soruları cevaplama, tahminlerin doğruluğunu, soruların cevaplarını, okuma amacına ulaşılıp ulaşılmadı̆̆ını kontrol etme, özetleme, metni ve kendini değerlendirme stratejileri üzerinde durulmuştur. Deney2 grubunda okuma öncesinde amaç belirleme, tahmin etme, görselden yararlanma, metnin biçimsel özelliklerine bakma; okuma sırasında not alma, anladıklarını kendi cümleleriyle ifade etme, tekrar okuma, yavaş okuma, sesli okuma, kaynaktan yararlanma, işaretleme, altını çizme, belli bir yere kadar okuyup düşünme, okuduklarını tartışma, metindeki ipuçlarından yararlanarak anlamı bulma, tahmin etme, önceki bilgilerden yararlanma, düşünceler arası 
ilişki kurma, dikkat verme; okuma sonrasında ise soruları cevaplama, tahminlerin/cevapların doğruluğu, okuma amacına ulaşııp ulaşılmadığını kontrol etme, özetleme, metni ve kendini değerlendirme stratejileri üzerinde durulmuştur. Bu işlem her hafta ders akışına uygun olarak bütüncül bir şekilde devam etmiştir. Uygulamada haftalık olarak üzerinde durulan bir aşama ya da strateji bulunmamaktadır. Deneysel işlem süreci tablo 3'te gösterilmiştir.

Tablo 3.

Deneysel işlem Süreci

\begin{tabular}{|c|c|c|c|}
\hline Deneysel İşlem & Deney1 & Deney2 & Kontrol grubu \\
\hline 1. hafta & $\begin{array}{l}\text { Bilişsel farkındalık } \\
\text { okuma stratejilerinin } \\
\text { ver uygulamada } \\
\text { kullanılacak stratejinin } \\
\text { tanıtılması }\end{array}$ & $\begin{array}{l}\text { Bilişsel farkındalık okuma } \\
\text { stratejilerinin ve } \\
\text { uygulamada kullanılacak } \\
\text { stratejinin tanıtılması }\end{array}$ & - \\
\hline 2. hafta & $\begin{array}{l}\text { Öğretmenin "rehber" } \\
\text { olduğu, açık strateji } \\
\text { öğretimi yaklaşımının } \\
\text { benimsendiği ve SQ4R } \\
\text { bütüncül okuma } \\
\text { stratejisinin } \\
\text { kullanıldığı deneysel } \\
\text { islem }\end{array}$ & $\begin{array}{lrr}\text { Öğretmenin } & \text { stratejileri } \\
\text { açıklayarak } & \text { "model" } \\
\text { olduğu, açık } & \text { strateji } \\
\text { öğretimi } & \text { yaklaşımının } \\
\text { benimsendiği } & \text { ve ESO } \\
\text { bütüncül } & \text { okuma } \\
\begin{array}{l}\text { stratejisinin } \\
\text { denevsel islem }\end{array} & \text { kullanıldığı }\end{array}$ & $\begin{array}{l}\text { Mevcut Türkçe Öğretim } \\
\text { programına göre derslere } \\
\text { devam edilmiştir. } \\
\text { Öğretmen rehber, } \\
\text { stratejiler bağımsız ve } \\
\text { örtük bir yaklaşımla dersin } \\
\text { içeriğinde yer almışıtır. }\end{array}$ \\
\hline 3. hafta & “ & " & “ \\
\hline 4. hafta & “ & " & “ \\
\hline 5. hafta & “ & “ & “ \\
\hline 6. hafta & $\begin{array}{l}\text { Ara değerlendirme ve } \\
\text { dönüt }\end{array}$ & $\begin{array}{l}\text { Ara değerlendirme ve } \\
\text { dönüt }\end{array}$ & - \\
\hline 7. hafta & “ & “ & - \\
\hline 8. hafta & “ & “ & - \\
\hline 9. hafta & “ & “ & - \\
\hline 10. hafta & “ & “ & - \\
\hline
\end{tabular}

Nitel Süreç: Nicel süreç tamamlandıktan sonra görüşmeler gönüllü öğrencilerle okulun Z kütüphanesinde yapılmıştır. Görüşmeler 10-20 dk. arasında sürmüş, ses kayıt cihazına kaydedildikten sonra yazıya aktarılmıştır.

\section{Verilerin Analizi}

Nicel Süreç: Veriler SPSS 22 yazılımıyla analiz edilmiştir. Ön-test son-test puanları arasındaki farkları karşılaştırmak için t-testi ve tek yönlü varyans analizi yapılmışır. Farklılaşmanın hangi gruplar arasında olduğunu belirlemek için Sheffe analizi yapılmıştır. Ortalama puanlar arası farkların farkını belirlemek için ise ANOVA ve LSD analizi yapılmıştır.

Bu çalışmada yer alan deney ve kontrol gruplarındaki öğrenci sayısı 30 ve üzerindedir. Merkezi limit teoremine göre, normal dağıııma sahip bir evrenden gelen ve bağımsız gözlemlerden oluşan yansız örneklemlerin her birinin örneklem büyüklüğü 30 ve üzerinde ise dağılımın normal dağılım gösterdiği belirtilmektedir. Dağılımın normalliği çeşitli yollardan sınanabilir. Bu çalışmada normallik betimsel yöntemle sınanmış ve çarpıklık (kurtosis) basıklık (skewness) katsayılarının \pm 2 sınırları içerisinde olduğu görülerek verilerin analizinde t testi, ANOVA gibi parametrik testlerden yararlanılmıştır.

Nitel Süreç: Görüşme kayıtlarının çözümlenmesinde MAXQDA 12 yazııımıyla betimsel analiz ve içerik analizi yapılmıştır. İçerik analiziyle, elde edilen verileri açıklayabilecek kavramlara ve ilişkilere ulaşmak amaçlanmaktadır. Bu sayede, betimsel analizle fark edilemeyen kavramlar ve temalar fark edilebilmektedir (Yıldırım ve Şimşek, 2013). 


\section{Geçerlik ve Güvenirlik}

Nitel araştırmada sonuçların aktarılabilirliği, dayandığı verilerin yeterli düzeyde betimlenmesine bağlıdır. Ayrıntılı betimleme, işlenmemiş verilerin ortaya çıkan kavram ve temalara göre yeniden düzenlenmiş bir biçimde, verilere yorum katmadan ve verinin doğasına uygun bir biçimde okuyucuya aktarılmasıdır. Bu amaçla araştırmacılar tarafından en sık kullanılan yöntemlerden biri doğrudan alıntılara yer vermektir (Yıldııı ve şimşek, 2013). Çalışmada aktarılabilirliği sağlamak amacıyla doğrudan alıntılara yer verilmiştir. Böylelikle araştırma sonuçlarının benzer ortamlara aktarılabilirliği gösterilerek dış geçerlilik sağlanmıştır.

Uzman görüşü doğrultusunda elde edilen verilerden kod ve temalar oluşturulmuştur. Kodlama işlemi yapılırken oluşturulan kodların ölçme aracında yer alan genel okuma, problem çözme ve okuma stratejilerini destekleme faktörleriyle uyumlu olup olmadığı kontrol edilmiştir. Oluşturulan kodlar önceden oluşturulan kavramsal çerçeveye uygun olarak okuma öncesi, okuma sırası ve okuma sonrası (Israel, 2007; Duffy, 2009) olarak kendi içinde temalara ayrılarak kodlarla temaların uygunluğu kontrol edilmiş ve böylelikle iç geçerlik sağlanmıştır. Literatür desteğinde oluşturulan kod ve temalar benzer çalışmalara aktarılabilir niteliktedir.

Nitel araştırmada, araştırmanın deseninden, toplanan verilere, bunların analizine ve sonuçların yazımına kadar, uzmandan yapılan araştırmayı çeşitli boyutlarıyla incelemesinin istenmesi verilerin inandırıcılığını sağlamak amacıyla başvurulabilecek yollardan biridir (Yıldırım ve Şimşek, 2013). Bu çalışmada da çalışmanın inandırıcılığına katkı sağlanması amacıyla ham veriler ve kodlama sonrası veriler uzmanlar tarafından incelenmiştir. Güvenirliği sağlamak için araştırmacının yaptığı kodlamaların tutarlıı̆̆ başka bir araştırmacı tarafından kontrol edilmiştir. Bununla birlikte elde edilen sonuçların ham verilerle uyumlu olup olmadığı teyit edilmiştir (Yıldırım ve Şimşek, 2013). Öğrenci görüşleri Deney1 grubunda katılımcı (K); Deney2 grubunda öğrenci (Ö) şeklinde kodlanmıştır.

\section{Varsayım ve Sınırlılıklar}

Öğrencilerin uygulama sürecine gönüllü olarak katıldıkları ve veri toplama araçlarının 6. sınıf öğrencilerinin okuma stratejileri bilişsel farkındalık becerilerini belirlemede yeterli olduğu varsayılmıştır. Bu çalışma 6. sınıf düzeyi, öyküleyici metin türü, SQ4R ve ESO bütüncül okuma stratejileriyle sınırlıdır.

\section{Araştırma ve Yayın Etiği}

Bu çalışmada "Yükseköğretim Kurumları Bilimsel Araştırma ve Yayın Etiği Yönergesi" kapsamında uyulması belirtilen tüm kurallara uyulmuştur. Yönergenin ikinci bölümü olan "Bilimsel Araştırma ve Yayın Etiğine Aykırı Eylemler" başlığı altında belirtilen eylemlerden hiçbiri gerçekleştirilmemiştir. Ölçek kullanımı ve görüşmeler için ilgili kişilerden/kurumlardan izin alınmıştır.

\section{1. alt probleme ilişkin bulgular}

\section{Bulgular}

Tablo 4.

Deney1, Deney2 ve Kontrol Grubundaki Öğrencilerin Okuma Stratejileri Bilişsel farkındalık Düzeyleri Ön-test Sonuçlarına Ait Tek Yönlü Varyans Analizi

\begin{tabular}{llllll}
\hline & & Karelertoplamı & sd & F & $\mathrm{p}$ \\
\hline Okuma stratejileri & Gruplararası & 0,383 & 2 & 0,685 & 0,50 \\
Bilişsel farkındalık & Grupiçi & 25,730 & 92 & & \\
toplamı (ön-test) & Toplam & 26,113 & 94 & & \\
\hline
\end{tabular}

Tablo 4'e bakıldığında okuma stratejileri bilişsel farkındalık toplamı ön-test sonuçlarına göre Deney1(SQ4R), Deney2 (ESO) ve kontrol grupları arasında istatistiksel olarak anlamlı fark görülmemiştir $(F(2,92)=0,685 ; p>0,05)$. 
Strateji Öğretiminde Kullanılan Farklı Yaklaşımların Öğrencilerin Okuma Stratejileri Üstbilişsel Farkındalık Becerilerine Etkisi

Tablo 5.

Deney1 (SQ4R) Grubundaki Öğrencilerin Okuma Stratejileri Bilişsel Farkındalık Düzeyleri Ön-Test SonTest Sonuçlarına Ait ilişkili t-Testi

\begin{tabular}{lcccccc}
\hline & $\overline{\mathrm{X}}$ & $\mathrm{N}$ & $\mathrm{S}$ & $\mathrm{t}$ & $\mathrm{sd}$ & $\mathrm{p}$ \\
\hline Bilişsel farkındalık Toplamı ön-test & 3,147 & 32 & 0,528 & $-5,871$ & 31 & 0,000 \\
Bilişsel farkındalık Toplamı son-test & 3,836 & 32 & 0,580 & & & \\
\hline
\end{tabular}

Tablo 5'e göre Deney1 grubundaki öğrencilerin toplamdaki okuma stratejileri bilişsel farkındalık düzeylerinde istatiksel olarak anlamlı fark görülmektedir $(t(31)=-5,871 ; p<.05)$. Aritmetik ortalamalara göre okuma stratejileri bilişsel farkındalık ön-test ortalamasının $(\bar{X}=3,147)$, son-test ortalamasından $(\bar{X}=3,836)$ düşük olduğu görülmüştür.

Tablo 6.

Deney2 (ESO) Grubundaki Öğrencilerin Okuma Stratejileri Bilişsel Farkındalık Düzeyleri Ön-Test SonTest Sonuçlarına Ait ilişkili t-Testi

\begin{tabular}{lccccccc}
\hline & $\overline{\mathrm{X}}$ & $\mathrm{N}$ & $\mathrm{S}$ & $\mathrm{t}$ & $\mathrm{sd}$ & $\mathrm{p}$ \\
\hline Bilişsel farkındalık Toplamı ön-test & 3,248 & 33 & & 0,559 & $-7,948$ & 32 & 0,000 \\
Bilişsel farkındalık Toplamı son-test & 4,164 & 33 & 0,491 & & & \\
\hline
\end{tabular}

Tablo 6'ya göre Deney2 grubundaki öğrencilerin toplamdaki okuma stratejileri bilişsel farkındalık düzeylerinde istatistiksel olarak anlamlı fark görülmüştür $(t(32)=-7,948 ; p<.05)$. Aritmetik ortalamalara göre okuma stratejileri bilişsel farkındalık ön test ortalamasının $(\bar{X}=3,248)$, son test ortalamasından $(\bar{X}=4,164)$ düşük olduğu görülmüştür.

Tablo 7.

Kontrol Grubundaki Öğrencilerin Okuma Stratejileri Bilişsel Farkındalık Düzeyleri Ön-Test Son-Test Sonuçlarına Ait iliş̧kili t-Testi

\begin{tabular}{|c|c|c|c|c|c|c|}
\hline & $\bar{x}$ & $\mathrm{~N}$ & $\mathrm{~S}$ & $\mathrm{t}$ & sd & $\mathrm{p}$ \\
\hline Bilişsel farkındalık Toplamı ön-test & 3,298 & 30 & 0,534 & 0,057 & 29 & 0,955 \\
\hline Bilişsel farkındalık Toplamı son-test & 3,291 & 30 & 0,592 & & & \\
\hline
\end{tabular}

Tablo 7'ye göre Kontrol grubundaki öğrencilerin toplamdaki okuma stratejileri bilişsel farkındalık düzeylerinde istatistiksel olarak anlamlı fark görülmemiştir ( $p>05)$.

Tablo 8.

Deney1 (SQ4R), Deney2 (ESO) ve Kontrol Grubundaki Öğrencilerin Okuma Stratejileri Bilişsel farkındalık Düzeyleri Son-test Sonuçlarına Ait Tek Yönlü Varyans Analizi

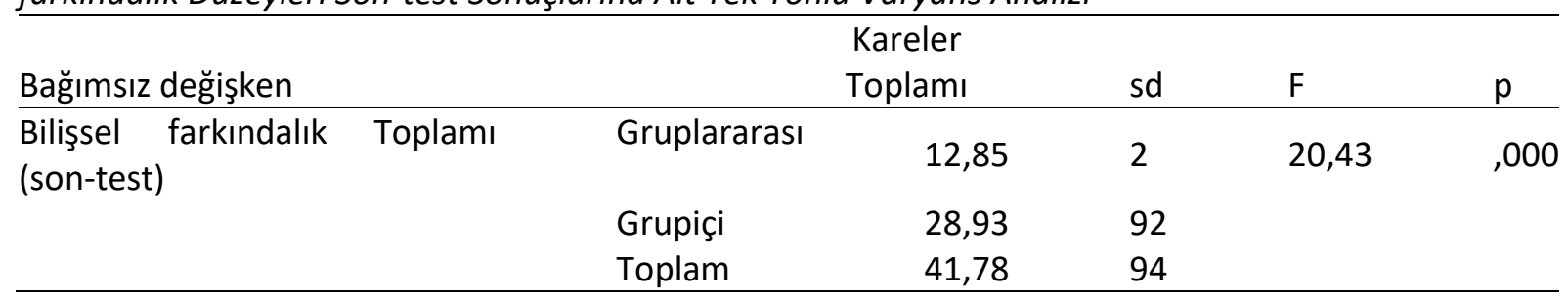

Tablo 8'e bakıldığında okuma stratejileri bilişsel farkındalık toplam düzeyleri son-test sonuçlarına göre Deney1, Deney2 ve kontrol grupları arasında istatistiksel olarak anlamlı fark 
görülmüştür $(F(2,92)=20,43 ; p<0,05)$. Farklılığın hangi gruplar arasında olduğunu belirlemek için Scheffe testi yapılmıştır.

Tablo 9.

Deney1 (SQ4R), Deney2 (ESO) ve Kontrol Grubundaki Öğrencilerin Okuma Stratejileri Bilişsel farkındalık Düzeyleri Son-test Sonuçlarına Ait Scheffe Testi

\begin{tabular}{lcccccc}
\hline Bağımsız Değişken & Grup (i) & Grup $(\mathrm{j})$ & $\overline{\mathrm{x}}(\mathrm{i})$ & $\overline{\mathrm{x}}(\mathrm{j})$ & Ortalamalar farkı (I-J) & $\mathrm{p}$ \\
\hline \multirow{3}{*}{ Bilişssel farkındalık toplamı } & Deney1 & Deney2 & 3,85 & 4,17 & $-0,32$ & 0,07 \\
& Deney2 & Kontrol & 4,17 & 3,27 & $0,90^{*}$ & 0,00 \\
& Deney1 & Kontrol & 3,85 & 3,27 & $0,57^{*}$ & 0,00 \\
\hline
\end{tabular}

Tablo 9'a göre Deney1 grubundaki öğrencilerin son-test ortalamaları $(\bar{X}=3,85)$ Deney2 grubundakilerin son test ortalamalarından $(\overline{\mathrm{X}}=4,17)$ düşüktür ancak bu fark istatistiksel olarak anlamlı değildir $(p>0,05)$. Deney2 grubundakilerin son-test puanları $(\bar{x}=4,17)$ kontrol grubundakilerin son test puan ortalamalarından $(\bar{X}=3,27)$ istatistiksel olarak anlamlı derecede yüksektir $(p<0.05)$. Deney1 grubundakilerin son-test puanları $(\overline{\mathrm{X}}=3,85)$ kontrol grubundakilerin son-test puan ortalamalarından $(\bar{X}=3,27)$ istatistiksel olarak anlamlı derecede $(p<0,05)$ yüksektir.

Tablo 10.

Deney1 (SQ4R), Deney2 (ESO) ve Kontrol Gruplarının Okuma Stratejileri Bilişsel Farkındalık Düzeyleri Ortalama Puan Farklarının Farkına iliş̧kin Varyans Analizi Sonuçları

\begin{tabular}{llrrrrr}
\hline & \multicolumn{5}{c}{ Kareler } & \multicolumn{4}{c}{ Kareler } \\
Toplamı & sd & Ortalaması & F & p \\
\hline Bilişsel Farkındalık Ortalama & Gruplararası & 14,308 & 2 & 7,154 & 16,691 & 0,000 \\
Puan Farklarının farkı & Grupiçi & 39,433 & 92 & 0,429 & & \\
& Toplam & 53,741 & 94 & & & \\
\hline
\end{tabular}

Tablo 10'a göre Deney ve kontrol gruplarının okuma stratejileri bilişsel farkındalık puan ortalamalarının farklarının farkına ilişkin bilişsel farkındalık düzeyleri $(F=16,691$ sd: 2-92, $p<0.05$ ) farklılık göstermektedir.

Tablo 11.

Deney1, Deney2 ve Kontrol Gruplarının Okuma Stratejileri Bilişsel Farkındalık Düzeyleri Ortalama Puan Farklarının Farkına ilişskin LSD Analizi Sonuçları

\begin{tabular}{lllccl} 
Bağımlı Değişken & & \multicolumn{2}{c}{ Ortalamalar Farkı (I-J) } & se & p \\
\hline Bilişsel Farkındalık & Deney 1 & Deney 2 Grubu & $-0,225$ & 0,162 & 0,168 \\
Ortalama Puan & Grubu & Kontrol Grubu & $0,697^{*}$ & 0,166 & 0,000 \\
Farklarının Farkı & Deney 2 & Deney 1 Grubu & 0,225 & 0,162 & 0,168 \\
& Grubu & Kontrol Grubu & $0,921^{*}$ & 0,165 & 0,000 \\
& Kontrol & Deney 1 Grubu & $-0,697^{*}$ & 0,166 & 0,000 \\
& Grubu & Deney 2 Grubu & $-0,921^{*}$ & 0,165 & 0,000 \\
\hline
\end{tabular}

Tablo 11'e bakıldığında Deney1 (SQ4R) ve Deney2 (ESO) grubunda bulunan öğrencilerin okuma stratejileri bilişsel farkındalık puan ortalamaları farkları ile kontrol grubundaki öğrencilerin ortalama puan farklarının farkı karşılaştırıldığında Deney1 ve Deney2 grubundaki öğrencilerin lehine fark $(p<0.05)$ görülmektedir. Deney1 ve Deney2 grubunda ise fark bulunmamaktadır $(p>0.05)$. 
Strateji Öğretiminde Kullanılan Farklı Yaklaşımların Öğrencilerin Okuma Stratejileri Üstbilişsel Farkındalık Becerilerine Etkisi

\section{2. alt probleme ilişkin bulgular}

Tablo 12.

Deney1 ve Deney2 Gruplarının Genel Okuma Stratejilerine Illişkin Görüşleri

\begin{tabular}{|c|c|c|}
\hline $\begin{array}{l}\text { Bilişsel farkındalık Okuma Stratejileri } \\
\text { Genel Okuma Stratejileri }\end{array}$ & $\begin{array}{l}\text { Deney1 } \\
\text { (SQ4R öğretmenin } \\
\text { rehber olduğu) } \\
\quad f\end{array}$ & $\begin{array}{l}\text { Deney2 } \\
\text { (ESO öğretmenin } \\
\text { model olduğu) } \\
\quad f\end{array}$ \\
\hline \multicolumn{3}{|l|}{ 1. Okuma Öncesi } \\
\hline a) Okuma amacı belirleme & 13 & 15 \\
\hline b) Tahmin etme & 13 & 14 \\
\hline c) Göz gezdirme & 9 & 12 \\
\hline d) Tablo, resim ve şekillerden faydalanma & 9 & 10 \\
\hline e) Yazı tipine dikkat etme & 0 & 10 \\
\hline f) Uzunluk ve düzenleme konularına bakma & 2 & 6 \\
\hline g) İçerik ipuçlarından faydalanma & 0 & 2 \\
\hline \multicolumn{3}{|l|}{ 2. Okuma Sırası } \\
\hline a) Not alma & 12 & 14 \\
\hline b) Yazı tipine dikkat etme & 7 & 4 \\
\hline c) İçerik ipuçlarından faydalanma & 5 & 9 \\
\hline d) Önemli yerlere karar verme & 4 & 12 \\
\hline \multicolumn{3}{|l|}{ 3. Okuma Sonrası } \\
\hline $\begin{array}{l}\text { a) Okuma amacına ulaşma } \\
\text { b)Metindeki bilgi ve bulguları değerlendirip analiz }\end{array}$ & 5 & 13 \\
\hline etme & 11 & 6 \\
\hline $\begin{array}{l}\text { c)Tahminlerin/cevapların doğruluğunu kontrol } \\
\text { etme }\end{array}$ & 13 & 27 \\
\hline $\begin{array}{l}\text { d)Çelişen bilgilere rastlanıldığında düşünceleri } \\
\text { gözden geçirme }\end{array}$ & 5 & 5 \\
\hline
\end{tabular}

Tablo 12'de Deney1 (SQ4R) grubunda görüşme yapılan öğrencilere okuma öncesinde neler yaptıkları sorulduğunda okuma amacı belirleme (13/16), tahmin etme (12/16), göz gezdirme (9/16), tablo, resim ve şekillerden faydalanma (9/16), uzunluk ve düzenleme konularına bakma (2/16) gibi genel okuma stratejilerini kullandıklarını belirtmişlerdir. Buna ilişkin örnek görüş şöyledir:

"Soruları gözden geçiririm. Metnin altında soru varsa ilk önce sorulara bakarım ve metni ona göre okuyorum okuma amacımı belirliyorum ve metne göz gezdiriyorum." (K14)

Okuma sırasında ve okurken zorlanılan durumlarda ise not alma (12/16), yazı tipine dikkat etme (7/16), içerik ipuçlarından yararlanma $(5 / 16)$ ve önemli yerlere karar verme $(4 / 16)$ gibi genel okuma stratejilerini kullandıklarını belirtmişlerdir. Bu duruma ilişkin örnek görüş şöyledir:

"Altını çizerim veya bir yere not ederim, okumayı bitirdikten sonra ne olduğuna bakarım geri dönüp anlamaya çalışııım." (K7)

Okuma sonrasında da okuma amacına ulaşma (5/16), metindeki bilgi ve bulguları değerlendirip analiz etme (11/16), tahminlerin/cevapların doğruluğunu kontrol etme (13/16), çelişen bilgilere rastlanıldığında düşünceleri gözden geçirme (5/16) gibi genel okuma stratejilerini kullandıklarını belirtmişlerdir. Bununla ilgili örnek görüş şöyledir:

"O metnin sorularını yanıtlarım o metinle ilgili birazcık düşünürüm bu metinde öğrendiklerimi hayatımın neresinde kullanırım diye düşünürüm. Hocam o metinden aldığım bilgileri mümkünse sınavlarımda kullanmaya çalışırım." (K8)

Deney2 (ESO) grubunda görüşme yapılan öğrencilere okuma öncesinde neler yaptığı sorulduğunda okuma amacı belirleme (15/16), tahmin etme (14/16), göz gezdirme (12/16), tablo, 
resim ve şekillerden faydalanma (10/16), uzunluk ve düzenleme konularına bakma (6/16), yazı tipine dikkat etme (10/16), içerik ipuçlarından faydalanma (2/16) gibi genel okuma stratejilerini kullandıklarını belirtmişlerdir. Okuma öncesinde kullanılan genel okuma stratejilerine ilişkin örnek görüş şöyledir:

"Metnin başlığına, metnin sorularına, kalın renkli yazılara, metnin uzunluğuna yazara bakıp tahmin yürütürüm." (Ö9)

Okuma sırasında ve okurken zorlanılan durumlarda ise not alma (14/16), yazı tipine dikkat etme (4/16), içerik ipuçlarından yararlanma (9/16) ve önemli yerlere karar verme (12/16) gibi genel okuma stratejilerini kullandıklarını belirtmişlerdir. Bununla ilgili örnek görüş şöyledir:

"Okurken not alııım orada (okuduğum kısımda) bilmediğim kelime olabilir. Bunların anlamlarına bakmaya çalışırım dikkatimi çeken yerleri unutmamak için notlar alırım." (Ö5)

Okuma sonrasında da okuma amacına ulaşma (13/16), metindeki bilgi ve bulguları değerlendirip analiz etme (6/16), tahminlerin/cevapların doğruluğunu kontrol etme (27/16), çelişen bilgilere rastlanıldığında düşünceleri gözden geçirme (5/16) gibi genel okuma stratejilerini kullandıklarını belirtmişlerdir. Bununla ilgili örnek görüş şöyledir:

"Tahminimin doğru olup olmadığına dikkat ederim. Tahminimle metnin içeriğini karşılaştırırım. Metin sonrası sorulara bakar, kendimi değerlendiririm." (Öو)

\section{3. alt probleme ilişkin bulgular}

Tablo 13.

Deney1 ve Deney2 Gruplarının Problem Çözme Stratejilerine iliş̧in Görüşleri

\begin{tabular}{|c|c|c|}
\hline $\begin{array}{l}\text { Bilişsel farkındalık Okuma Stratejileri } \\
\text { Problem Çözme Stratejileri }\end{array}$ & $\begin{array}{l}\text { Deney1 (SQ4R öğretmenin } \\
\text { rehber olduğu) } \\
\qquad f\end{array}$ & $\begin{array}{l}\text { Deney2 (ESO öğretmenin } \\
\text { model olduğu } \\
\quad f\end{array}$ \\
\hline \multicolumn{3}{|l|}{ 1. Okuma Sırası } \\
\hline a) Tekrar okuma & 14 & 14 \\
\hline b) Okunan şeye dikkat verme & 6 & 6 \\
\hline $\begin{array}{l}\text { c) Belli yerlerde durup düşünme } \\
\text { d) Kelime ve cümlelerin anlamını tahmin }\end{array}$ & 6 & 10 \\
\hline etme & 5 & 15 \\
\hline e) Okurken metni tahmin etme & 3 & 2 \\
\hline f) Yavaş okuma & 4 & 0 \\
\hline g) Zihinde canlandırma & 2 & 0 \\
\hline h) Önceki bilgileri harekete geçirme & 1 & 0 \\
\hline ı) Okunan kısmı başkasından dinleme & 0 & 2 \\
\hline
\end{tabular}

Tablo 13'te Deney1 (SQ4R) grubunda görüşme yapılan öğrencilere okurken zorlanılan durumlarda hangi stratejilere başvurdukları sorulduğunda tekrar okuma (14/16), okunan şeye dikkat verme (6/16), belli yerlerde durup düşünme (6/16), kelime ve cümlelerin anlamını tahmin etme (5/16), okurken metni tahmin etme (3/16), yavaş okuma (3/16), zihinde canlandırma (2/16), önceki bilgileri harekete geçirme (1/16) gibi problem çözme stratejilerinin kullanıldığı belirtilmiştir. Problem çözme stratejilerinin okuma sırasında kullanıldığı görülmektedir. Bununla ilgili örnek görüşler şöyledir:

"Tekrar tekrar okurum. Metnin okuduğum kısmı ile diğer kısmı arasında bağ kurarak anlamaya çalışırım." (K4)

"Bir kitabı veya metni okurken öncelikle ara ara durup o kısımda neler olduğunu not eder veya hayal ederim" (K12)

"Bazen de önce biraz durup yavaş sonra sesli okuyorum." (K3)

Deney2 (ESO) grubunda görüşmeye katılan öğrenciler okuma sırasında ve okurken zorlanılan durumlarda tekrar okuma (14/16), okunan şeye dikkat verme (6/16), belli yerlerde durup düşünme 
Strateji Öğretiminde Kullanılan Farklı Yaklaşımların Öğrencilerin Okuma Stratejileri Üstbilişsel Farkındalık Becerilerine Etkisi

(10/16), kelime ve cümlelerin anlamını tahmin etme (15/16), okurken metni tahmin etme (2/16), okunan şeyi başkasından dinleme (1/16) gibi problem çözme stratejilerini kullandıklarını belirtmişlerdir. Bununla ilgili örnek görüşler şöyledir:

"Anlamadığım kelimelere sözlükten bakmaya çalışııım. bilmiyorsam ilk olarak kendi kafamda tahminde bulunurum sonrasında sözlüğe bakarım veya öğretmenime sorarım." (Ö5)

"Bir yerlere not alırım bilmediğim kelimeleri ve anlamadığım yerleri not alırım ve o bölümleri tekrar okurum." (Ö14)

"Okuyup anlamazsam birisinin okumasını isterim belki o zaman daha iyi anlarım" (Ö10)

\section{4. alt probleme ilişkin bulgular}

Tablo 14.

Deney1 ve Deney2 Gruplarının Okuma Stratejilerini Desteklemeyle Ilgili Görüşleri

\begin{tabular}{|c|c|c|}
\hline Bilişsel farkındalık Okuma Stratejileri & $\begin{array}{l}\text { Deney1 } \\
\text { (SQ4R öğretmenin } \\
\text { rehber olduğu) }\end{array}$ & $\begin{array}{l}\text { Deney2 } \\
\text { (ESO öğretmenin model } \\
\text { olduğu }\end{array}$ \\
\hline Okuma Stratejilerini Destekleme & $f$ & $f$ \\
\hline \multicolumn{3}{|l|}{ 1. Okuma Öncesi } \\
\hline a) Soru oluşturma & 12 & 0 \\
\hline \multicolumn{3}{|l|}{ 2. Okuma Sırası } \\
\hline a) Önemli yerlerin altını çizme/yuvarlak içine alma & 21 & 19 \\
\hline b) Sözlük ve diğer kaynaklardan yararlanma & 16 & 22 \\
\hline c) Kendi sözcükleriyle yeniden ifade etme & 10 & 7 \\
\hline d) Yüksek sesle okuma & 5 & 3 \\
\hline $\begin{array}{l}\text { e) Okuduklarını başkalarıyla tartışma } \\
\text { f) Metinde İleri geri gidip düşünceler arası ilişki }\end{array}$ & 8 & 15 \\
\hline kurma & 8 & 12 \\
\hline g) Okuma sırasında kendine soru sorma & 1 & 6 \\
\hline \multicolumn{3}{|l|}{ 3. Okuma Sonrası } \\
\hline a) Soruları cevaplama & 13 & 8 \\
\hline b) Özetleme & 11 & 11 \\
\hline c) Okuduklarını başkalarıyla tartışma & 1 & 0 \\
\hline d) Sözlük ve diğer kaynaklardan yararlanma & 1 & 2 \\
\hline
\end{tabular}

Tablo 14'te Deney1 (SQ4R) grubunda görüşme yapılan öğrencilere okuma öncesinde neler yaptığı sorulduğunda metinle ilgili soru oluşturma (12/16) stratejisini kullandıklarını söylemişlerdir. Bu stratejinin gelişmesinde uygulamada kullanılan SQ4R stratejisinin etkili olduğu söylenebilir çünkü okuma öncesi soru oluşturma SQ4R okuma stratejisinin bir adımıdır. Bununla ilgili örnek görüş şöyledir:

"Resimlere bakarak başlık ne olabilir diye, ne anlatıyor diye tahminler yapıyoruz ve sonra bununla ilgili sorular oluşturuyoruz." (K2)

Öğrenciler okuma sırasında önemli yerlerin altını çizme/yuvarlak içine alma (21/16), sözlük ve diğer kaynaklardan yararlanma (16/16), kendi sözcükleriyle yeniden ifade etme (10/16), okuduklarını başkalarıyla tartışma (8/16), yüksek sesle okuma (5/16), metni okurken kendine soru sorma $(1 / 16)$, metinde ileri geri giderek düşünceler arası ilişkileri bulma (8/16) gibi stratejileri kullandıklarını belirtmişlerdir. Bununla ilgili örnek görüşler şöyledir:

"Anlamadıklarımın altını çizerim metin bittikten sonra sözlükten bakılabilir bir şeyse oradan bakarım bakılamayacak bir şeyse internetten tabletten araştırııı." (K13)

"Metnin okuduğum kısmı ile diğer kısmı arasında bağ kurarak anlamaya çalışııı." (K4) 
Öğrenciler okuma sonrasında da soruları cevaplama (13/16), özetleme (11/16), okuduklarını başkalarıyla tartışma (1/16), sözlük ve diğer kaynaklardan yararlanma (1/16) gibi stratejileri kullandıklarını ifade etmişlerdir. Bununla ilgili örnek görüşler şöyledir:

"Özetini çıkartırım ve önemli yerleri not ederim." (K1)

"Okuma öncesi hazırladığım sorulara cevap buluyordum." (K12)

Deney2 (ESO) grubunda görüşme yapılan öğrenciler okuma sırasında önemli yerlerin altını çizme/yuvarlak içine alma (19/16), sözlük ve diğer kaynaklardan yararlanma (22/16), kendi sözcükleriyle yeniden ifade etme (7/16), okuduklarını başkalarıyla tartışma (15/16), yüksek sesle okuma (3/16), metni okurken kendine soru sorma/cevaplama (6/16), metinde ileri geri giderek düşünceler arası ilişkileri bulma (12/16) gibi stratejileri kullandıklarını belirtmişlerdir. Bununla ilgili örnek görüşler şöyledir:

"Bilmediğim kelimelere dikkat ederim. Bilmiyorsam altını çizerim ya da ünlem gibi bir işaret koyarım yanına." (Ö13)

"ilk olarak tek başıma kitap okuyorsam anlamadığım kelimeyi sözlükten bakarım ama ögrretmenim varsa ve yanımda sözlük yoksa hocama sorarım." (Ö5)

Okuma sonrasında da soruları cevaplama (8/16), özetleme (11/16), sözlük ve diğer kaynaklardan yararlanma (1/16) gibi stratejileri kullandıklarını ifade etmişlerdir. Bununla ilgili örnek görüşler şöyledir:

"Metnin sorularını cevaplarım ve doğru yaptım mı diye kontrol ederim kontrol ederken doğru ve yanlışın farkına varmış olurum." (Ö12)

"Anlayıp anlamamış mıyım diye özet çıkartıım." (Ö10)

\section{Tartışma ve Sonuç}

Strateji öğretiminde genellikle "açık" ve "örtük" olmak üzere iki yaklaşım kullanılmaktadır. Birçok araştırmacı bilişsel farkındalık bilgisinin ve stratejilerinin açık strateji öğretimiyle öğretilmesi gerektiğini belirtmektedir (Paris ve Myers, 1981; Billingsley ve Wildman, 1990; Dole vd., 1991; Schraw ve Moshman, 1995; Randi ve Corno, 2000; Veenman vd., 2006; Archer ve Hughes, 2011) çünkü çoğu öğrenci bilişsel farkındalık becerisini kendiliğinden geliştirip kullanamamaktadır (Lin, 2001; Hartman, 2002; Pintrich, 2002; Pressley, 2002; Nokes ve Dole, 2004). Ancak yapılan araştırmalar öğretmenlerin çoğunun strateji öğretiminde örtük yaklaşımı benimsediğini göstermektedir (Jacobs ve Paris, 1987; Pintrich, 2002; Kistner vd., 2010; Peteranetz, 2014).

Açık strateji öğretimi, öğretmen kontrolünde (teacher-led) öğrencinin ihtiyaç duyduğu durumlarda gerekli müdahaleleri yapmayı gerektirir (Billingsley ve Wildman, 1990). Öğretim sürecinde öğretmen öğrencilerin kendi öğrenmelerinin farkında olmalarını sağlamaya çalışır, öğrenciler ise öğrenmelerini anlamaya/fark etmeye çalışır (Dole vd., 1991). Açık(lamalı) öğretimde örtük öğretimin aksine öğretmen öğrencilere belli bir stratejiyi kullanmalarını söyleyebilir, stratejinin anlam ve önemi hakkında bilgi verebilir ve stratejinin hangi durumlarda nasıl kullanılacağını söyleyebilir (Kistner vd., 2015). Açıklamalı olarak yapılan strateji eğitimi, "bilgilendirilmiş eğitim" olarak adlandırımaktadır. Brown vd. (1981'den akt. Kistner vd., 2010) yapmış olduğu çalışmada bilgilendirilmiş eğitimde öğrencilerin öğrendikleri stratejileri kendi başlarına başka durumlarda kolaylıkla uygulayabildiğini ancak "kör" yani örtük öğretimde öğrencilerin, stratejileri farklı durumlarda uygulamakta güçlük çektiği yani strateji kullanımını genelleştiremedikleri sonucuna ulaşmıştır.

Günümüzde eğitim sistemlerinin amacı, öğrencilere kendi öğrenmelerinde aktif ve amaçı bir rol almalarını sağlayarak kendi öğrenme sürecini düzenleyebilme becerisi kazandırmaktır (Driscoll, 2012). SQ4R okuma stratejisi kişilerin kendi öğrenme-okuma süreçlerini izlemelerine ve kontrol etmelerine imkân vererek bilgiyi işleme sürecini yöneten bilişsel farkındalığın gelişmesine katkı sağlar. Okuma sürecinde planlama, izleme ve değerlendirme davranışlarını alışkanlık hâline getiren öğrenciler bağımsız birer okuyucu olurlar (Coon ve Mitterer, 2011; Wong, 2012). Bu noktada, SQ4R stratejisinin etkili olmasında kullanılan öğretim yaklaşımının da etkili olacağı söylenebilir. SQ4R, öğretmen rehberliğinde yapılan bir strateji olduğu için öğretimin açık veya örtük olması öğretmenin inisiyatifindedir. Jairam vd. (2013) de SQ3R/SQ4R benzeri stratejilerin öğretiminde metodolojik hataların yapıldığını bu hataların da stratejinin etkinliğini etkilediğini belirtmiştir. Bu çalışmada SQ4R 
stratejisinin öğretmen rehberliğinde ve açık strateji öğretimi yaklaşımıyla uygulanmasının 6 . sınıf öğrencilerinin okuma stratejileri bilişsel farkındalık düzeylerinde anlamlı bir fark oluşturduğu söylenebilir.

ESO sürecinde öğretmen, öğrencilere kazandırmak istediği davranışları sesli düşünerek açıklar böylelikle kendi düşünme sürecini öğrencilere göstererek okuma sürecinde uygulanması gereken davranışların nerede, nasıl ve niçin kullanıldığıyla ilgili onlara model olur (Fountas ve Pinnell, 2006). Araştırmacılar ESO'nun ilkokuldan sonraki eğitim düzeylerinde de kullanılmasını desteklemektedir (Albright ve Arial, 2005; Lesesne, 2006; Robb, 2007; Hodges, 2011). Serafini ve Giorgis (2003) ortaokul ve lise düzeyindeki öğrencilerle yapılan ESO'nun öğrencilere 'metni derinlemesine anlama, metinle etkileşime girerek yeni bilgiler öğrenme ve metni anlamaya yardımcı olacak stratejileri görme ve uygulama' konusunda yardımcı olacağını belirtmiştir. Çeşitli araştırmalarda ESO'nun öğrencilerin temel dil becerilerinin yanı sıra, eleştirel düşünme ve problem çözme gibi yaşam becerilerini de geliştirdiği ifade edilmektedir (Johnstone, 2015). Yani ortaokul ve sonrasındaki eğitim düzeylerinde yapılan sesli okumanın amacı, öğrencilerin tek başlarına anlamaya zorlandıkları yerlerde metni derinlemesine anlayabilmeleri ve anlamanın nasıl gerçekleştiğine dair davranış kazandırma için kullanılmaktadır. Bu çalışmada da öğretmenin stratejileri açıklayarak model olduğu ESO'nun 6. sınıfa devam eden öğrencilerin okuma stratejileri bilişsel farkındalık düzeylerinde farklılık oluşturduğu görülmektedir.

Açık strateji öğretimi yaklaşımının benimsendiği Deney1 grubunda SQ4R, Deney2 grubunda ESO bütüncül okuma stratejileri kullanılmıştır. Bütüncül okuma stratejileri, belirli bir okuma görevine yönelik olarak okuma sürecinde kullanılması gereken stratejileri birbiriyle bağlantılı şekilde sunan stratejilerdir. Stratejilerin bütüncül olarak kullanılması yeni öğrenilen bilgilerin hafızaya alınmasına ve düzenlenmesine yardımcı olarak etkili bir öğrenmenin gerçekleşmesini sağlar. Hattie vd. (1996) de stratejilerin birbirinden bağımsız genel beceriler olarak öğretilmesindense belli bir içerik bağlamında bilişsel farkındalı̆̆ı ve kendi kendini düzenleme becerilerini işleten bütüncül stratejilerin kullanılmasının daha etkili olabileceğini belirtmiştir. Bu bakımdan deney gruplarında kullanılan SQ4R ve ESO bütüncül okuma stratejilerinin öğrencilerin bilişsel farkındalık becerilerine katkı sağladığı söylenebilir.

Deney gruplarında bulunan öğrencilerle yapılan görüşmeler de bu durumu desteklemektedir. SQ4R (Deney1) grubunda bulunan öğrencilerin okuma süreciyle ilgili bilişsel farkındalıklarını belirlemeye yönelik sorular sorulduğunda, uygulama sürecinde öğrendikleri stratejileri kapsamında sıklıkla; okuma amacı belirleme (13/16), tahmin etme (12/16), not alma (12/16) metindeki bilgi ve bulguları değerlendirip analiz etme (11/16), tahminlerin/cevapların doğruluğunu kontrol etme (13/16) gibi genel okuma stratejilerini kullandıklarını; okuma sırasında ve okurken zorlanılan durumlarda ise sıklıkla tekrar okuma (14/16) problem çözme stratejisini kullandıklarını; okuma stratejilerini destekleme stratejilerinden sıklıkla önemli yerlerin altını çizme/yuvarlak içine alma (21/16), sözlük ve diğer kaynaklardan yararlanma (16/16), soru oluşturma (12/16) kendi sözcükleriyle yeniden ifade etme $(10 / 16)$, soruları cevaplama (13/16), özetleme (11/16) gibi stratejileri kullandıklarını ifade etmişlerdir.

ESO (Deney2) grubunda öğrenciler sıklıkla okuma amacı belirleme (15/16), tahmin etme (14/16), göz gezdirme (12/16), tablo, resim ve şekillerden faydalanma (10/16), yazı tipine dikkat etme (10/16), okuma amacına ulaşma (13/16), tahminlerin/cevapların doğruluğunu kontrol etme (27/16), not alma (14/16), önemli yerlere karar verme (12/16) gibi genel okuma stratejilerini kullandıklarını belirtmişlerdir. Okuma sırasında ve okurken zorlanılan durumlarda ise tekrar okuma (14/16), belli yerlerde durup düşünme (10/16), kelime ve cümlelerin anlamını tahmin etme (15/16) gibi problem çözme stratejilerini kullandıklarını; okuma stratejilerini destekleme stratejilerinden sıklıkla önemli yerlerin altını çizme/yuvarlak içine alma (19/16), sözlük ve diğer kaynaklardan yararlanma (22/16), okuduklarını başkalarıyla tartışma (15/16), metinde ileri geri giderek düşünceler arası ilişkileri bulma $(12 / 16)$, soruları cevaplama ve özetleme (11/16) stratejilerini kullandıklarını ifade etmişlerdir.

Türkiye'de yapılan bu çalışmada kontrol grubunda Millî Eğitim Bakanlığı tarafından hazırlanan Türkçe ders kitapları kullanılmıştır. Öğretmen kılavuz kitaplarına bakıldığında stratejilerin öğretiminde yaklaşım olarak örtük yaklaşımın benimsendiği söylenebilir. Aşă̆ıda kılavuz kitaplarda yer alan okuma stratejilerini desteklemeye yönelik bir strateji ifadesi yer almaktadır: 
"Öğrencilerinizden anlamını bilmedikleri kelimeleri daire içine almalarını, metinde sıkıkla tekrar edilen kelimelerin ve önemli gördükleri cümlelerin de altını çizmelerini isteyiniz." (Tetik vd., 2016, s. 31).

Türkçe Öğretim Programının 2018 yılında revize edilmesiyle kılavuz kitap uygulaması kaldırımıştır ancak kitaplar incelendiğinde okuma eğitiminde stratejilerin örtük ve birbirinden bağımsız öğretilme yaklaşımının değişmediği söylenebilir:

"Metinde geçen anlamını bilmediğiniz kelime ve kelime gruplarını belirleyerek bunların anlamlarını tahmin ediniz." (Ceylan vd., 2018)

Görüldüğg̈ üzere Türkçe ders kitaplarında öğretmen metnin türüne göre sözleri ve davranışlarıyla öğrencileri strateji kullanmaya teşvik etmektedir. Ancak bu yapılırken öğrencilere kullanılan stratejinin önemi ya da nerede, nasıl kullanılacağıyla ilgili bilgi verilmemektedir. Öğrencilere herhangi bir stratejiyi kullanmaları da doğrudan tavsiye edilmemektedir (Kistner vd., 2015). Yani örtük bir strateji öğretimi gerçekleşmektedir. Schreiber (2005) örtük strateji öğretiminde yapılandırıcı yaklaşımın benimsendiğini belirtmektedir. Türkçe Öğretim Programlarında da 2006 yılından beri yapılandırıcı yaklaşım benimsenmiştir. Örtük strateji yaklaşımında öğretmen söz ve davranışlarıyla öğrenciyi strateji kullanmaya teşvik eder ancak stratejilerin nerede, nasıl kullanılacağıyla ilgili doğrudan bilgi vermez. Brown vd. (1981'den akt. Kistner vd., 2010) bu şekilde yapılan eğitimi "kör eğitim (blind training)" olarak adlandırmakta ve bu durumun, öğrencilerin stratejik bir okur olmalarını zorlaştırdığını belirtmektedir. Bununla birlikte kontrol grubunda strateji öğretimi bütüncül bir yaklaşım hâlinde değil ayrı ayrı yapılmaktadır. Araştırmadan elde edilen sonuca göre, okuma derslerinin Türkçe Öğretim Programına göre gerçekleştiği kontrol grubundaki öğrencilerin bilişsel farkındalık okuma stratejileri düzeylerinde bir farklılık görülmemektedir. Bunun mevcut programın örtük bir yaklaşımı benimsemesinden ve stratejileri bağımsız olarak öğretmesinden kaynaklandığı söylenebilir.

Sonuç olarak Deney1 ve Deney2 grubundaki öğrencilerin okuma stratejilerini destekleme, problem çözme, genel okuma stratejileri ve toplamdaki bilişsel farkındalık puan ortalamaları ile kontrol grubundaki öğrenciler karşılaştırıldığında Deney1 ve Deney2 grubundaki öğrencilerin lehine fark görülmektedir. Deney1 ve Deney2 grubunun kendi aralarında farklılık görülmemektedir. Bu sonucun ortaya çıkmasında öncelikle deney gruplarında stratejiler öğretilirken açık strateji öğretimi yaklaşımının; kontrol grubunda ise örtük strateji öğretim yaklaşımının benimsenmesinin etkili olduğu söylenebilir. İkinci olarak da deney gruplarındaki uygulamada bütüncül okuma stratejilerinin kullanılmasının; kontrol grubunda ise stratejilerin birbirinden bağımsı/ayrı öğretilmesinin etkili olduğu söylenebilir. Açık strateji öğretimi öğretmenin stratejileri açıklayarak model olması veya rehber olması şeklinde gerçekleşebilir. Nicel sonuçlarda anlamlı bir fark ortaya çıkmasa da nitel sonuçlara bakıldığında öğretmenin stratejileri açıklayarak model olduğu ESO'nun uygulandığı Deney2 grubunda bilişsel farkındalık okuma stratejilerinin (314), öğretmenin rehber olduğu SQ4R stratejisinin uygulandığı Deney1 grubundaki öğrencilerden (256) daha fazla kullanıldığı ifade edilmiştir. Yani kullanılan öğretim yaklaşımının öğrencilerin okuma stratejileri bilişsel farkındalık becerileri üzerinde etkili olduğu söylenebilir.

PISA 2018 sınavının raporuna göre Türkiye'de okuma becerisinde en çok 1a ve 2 seviyesinde öğrenci bulunmaktadır. 8 düzeyin bulunduğu bu değerlendirmede düzey 1 a ve 2 'deki öğrenciler metindeki açık bilgiyi bulabilen, metnin belli bir bölümünden anlam çıkarabilen, basit düzeyde metindeki ilişkileri anlayabilen ve kendi yaşantısıyla metin arasında basit ilişki kurabilen, kısa veya orta uzunlukta aşina oldukları metinlerin ana fikrini bulabilen (Millî Eğitim Bakanlığı, 2019) alt performans düzeyindeki öğrencileri temsil etmektedir. Bu rapordan alınan ortalama puanlara göre Türkiye 79 ülke içerisinde okuma becerisinde 40. sırada; OECD ülkeleri (37) içerisinde 31. sırada yer almıştır. Öğrenmenin büyük oranda okumaya dayandığı düşünüldüğünde okuma alanında öğrencilerin düşünme ve kendi kendini düzenleme becerilerini geliştirerek onları bağımsız okuyucular yapmaya yönelik strateji eğitimine önem verilmelidir.

$\mathrm{Bu}$ araştırmanın sonuçlarına göre, Türkiye gibi okuma becerilerinde düşük performans sergileyen ülkelerde strateji öğretiminde açık strateji öğretimi yaklaşımının benimsenmesinin ve metin türüne uygun olarak bütüncül okuma stratejileri kullanılmasının öğrencilerin okuma stratejileri bilişsel farkındalık becerilerinin geliştirilmesinde etkili olacağı söylenebilir. Çünkü mevcut ders kitaplarında 
strateji öğretimi birbirinden bağımsız ve örtük biçimde yapılmaktadır. Yani öğrenciler belli adımlarda hangi stratejileri nasıl kullanacaklarına dair eğitilmemektedir. Literatürde etkinliği kanıtlanmış bütüncül stratejiler okuma sürecinde kendi işleyiş yapılarından dolayı sınıf içerisinde öğretmen ve öğrenci rollerini belirlemektedir. Strateji konusunda eğitim almamış öğrencileri doğrudan stratejileri bağımsız (kendi başlarına) olarak kullanmaya yönlendiren bütüncül stratejilerden öğretmen de öğrenci de yeterince faydalanamayacaktır. Bu bakımdan stratejiler seçilirken öğrencilerin bu konudaki hazırbulunuşluğu da dikkate alınarak strateji seçimi yapılmalıdır.

Bu çalışmada dünyada ve ülkemizde çeşitli deneysel çalışmalarda etkinliği kanıtlanmış SQ4R ve ESO stratejileri kullanılmış ve nicel olarak yapılan değerlendirmeler sonucunda genel değerlendirmede bu iki stratejinin aralarında anlamalı fark olmadığı ortaya çıkmıştır. Konuyu derinleştirmek için yapılan görüşmelerde ise SQ4R stratejisinin uygulandığı gruplarda öğrencilerin okuma stratejileri farkındalığına dair üstbilişsel bilgisinin geliştiği; öğretmenin stratejileri açıklayarak model olduğu ESO stratejisinin uygulandığı sınıflarda ise öğrencilerin okuma stratejileri farkındalığına yönelik üstbilişsel bilgisinin yanı sıra stratejileri kullanma/uygulama düzeylerinin yani üstbilişsel deneyimlerinin de geliştiği sonucuna ulaşılmıştır. Yani öğretmenin rehber olduğu SQ4R grubunda öğrenciler konuyla ilgili bilgi sahibi olmuştur anket formuyla elde edilen nicel sonuçlar öğrencilerin üstbilişsel bilgisini göstermektedir. Ancak bireylerin genel olarak bir konuda özel olarak bu çalışma dâhilindeki okuma konusunda üstbilişsel bilgisinin olması ütsbilişsel deneyimi sergileyebileceği anlamına gelmez. Öğretmenin stratejileri açıklayarak model olduğu ESO grubunda öğrenciler okuma stratejileri konusunda hem üst bilişsel bilgiye hem de üst bilişsel deneyime sahip olmuştur. Öğrenmeyi öğrenme sürecinde üst bilişsel deneyim sahibi olmak önemli olduğundan öğretmenler strateji kullanımı konusunda eğitim almamış ya da farkındalığı oluşmamış öğrencilerle çalışırken öncelikle onlara model olarak kendi düşünme ve uygulama sürecini göstermeli; daha sonra öğrencilerin bağımsı uygulama yapacağı stratejilere yönelmelidir. Burada öğretmenin stratejileri açıklayarak model olması öğretmen merkezli (teachercenter) olmakla karıştırımamalıdır. Öğretmen bu süreci öğrencilerin hazırbulunuşluk durumunu düşünerek tüm ayrıntılarıyla planlamalı ve esas hedef olan öğrencilerin bağımsız okuyucular olabilmesi için dersin akışına uygun olarak stratejilerin nerede, nasıl ve niçin kullanıldığını öğretmen liderliğinde (teacher-lead) öğrencilerin öğrendiklerini deneyimlemelerine fırsat vererek öğrendiklerini sonraki uygulamalara aktarabilmeyi sağlayan sınıf içi düzenlemeler yapabilmelidir.

Planlı bir okuma stratejileri eğitiminin gerçekleştirilebilmesi için sınıf kademesine uygun düzenleme yapılabilir. Örneğin 5. sınıflarda öğretmenin stratejileri açıklayarak model olduğu; 6 ve 7 . sınıflarda öğretmenin stratejileri açıklayarak model ve rehber olduğu; 8. sınıflarda ise öğretmenin rehber olduğu ve öğrencilerin sınıf dışında da bağımsız uygulamalar yaptığı bütüncül stratejiler kullanılabilir. Tabii yapılacak uygulamalar bir kural gibi algılanmamalıdır. Öğrencilerin durumuna göre sınıf düzeyi gözetmeksizin gerektiği yerde açıklamalı gerektiği yerde örtük yaklaşıma imkân veren esnek bir yapının kullanılması öğrencilerin yararına olacaktır. İleriki zamanlarda farklı veya aynı sınıf düzeylerinde farklı metin türleri ve farklı bütüncül stratejilerle yapılacak deneysel çalışmalarla bu çalışmadan elde edilen sonuçlar sınanarak konuyla ilgili araştırmalar genişletilebilir.

\section{Araştırma ve Yayın Etiği}

Bu çalışmada "Yükseköğretim Kurumları Bilimsel Araştırma ve Yayın Etiği Yönergesi" kapsamında uyulması belirtilen tüm kurallara uyulmuştur. Yönergenin ikinci bölümü olan "Bilimsel Araştırma ve Yayın Etiğine Aykırı Eylemler" başlığı altında belirtilen eylemlerden hiçbiri gerçekleştirilmemiştir. Ölçek kullanımı ve görüşmeler için ilgili kişilerden/kurumlardan izin alınmıştır.

\section{Yazarların Katkı Oranı}

Makalenin hazırlanmasında 1. yazar \%60, 2. yazar \%40 oranında katkı sağlamıştır.

\section{Çıkar Çatışması}

Araştırmada çıkar çatışması teşkil edebilecek herhangi bir durum ya da ilişki bulunmamaktadır. 


\section{Kaynaklar}

Afflerbach, P., Pearson, P.D. ve Paris, S.G. (2008). Clarifying differences between reading skills and reading strategies. The Reading Teacher, 61(5), 364-373.

Albright, L.K. ve Ariail, M. (2005). Tapping the potential of teacher read alouds in middle schools. Journal of Adolescent\&Adult Literacy, 48(7), 582-591.

Archer, A.L. ve Hughes, C.A. (2011). Explicit instruction: Effective and efficient teaching. New York: Guilford Press.

Baker, L. ve Brown, A.L. (1984). Metacognitive skills and reading. P. D. Pearson, R. Barr, M. L. Kamil ve P. Mosenthal (Eds.), Handbook of reading research (ss. 353-394). New York: Longman.

Barbour, R.S. ve Schostak, J. (2005). Interviewing and focus groups. B. Somekh ve C. Lewin (Eds), Research methods in social sciences (ss. 41-49). London: Sage.

Billingsley, B.S. ve Wildman, T. M. (1990). Facilitating reading comprehension in learning disabled students: Metacognitive goals and instructional strategies. Remedial and Special Education, 11(2), 18-31.

Carter, C.E. (2011). Mindscapes: critical reading skills and strategies. USA: Wadsworth Cengage Learning.

Caverly, D.C., Orlondo, V.P. ve Mullan, J.L. (2000). Textbook study reading. Ronna F. Flippo ve David C. Caverley (Eds.), Handbook of collage reading and study strategy research (ss. 105-149). New York: Routledge.

Ceylan, S., Duru, K., Erkek, G. ve Pastutmaz, M. (2019). Ortaokul ve imam hatip ortaokulu Türkçe 6 ders kitabı. Z. Batur ve S. Ceylan (Ed.). Ankara: MEB.

Coon, D. ve Mitterer, J.O. (2011). Introduction to psychology: Gatewates to mind and behavior. USA, Belmont: Wadsworth, Cengage Learning.

Cuttler, C. (2017). Research methods in psychology. Erişim adresi: https://opentext.wsu.edu/carriecuttler/front-matter/about-this-book-2/.

Dole, J.A., Duffy, G.G., Roehler, L.R. ve Pearson, P.D. (1991). Moving from the old to the new. Research on reading comprehension instruction. Review of Educational Research, 61(2), 239-264.

Driscoll, M.P. (2012). Öğretim süreçleri ve öğrenme psikolojisi. (Çev. Ömer F. Tutkun, Seçil Okay ve Evrim Şahin). Ankara: Anı Yayıncılık.

Duffy, G. G. (2009). Explaining reading: A resource for teaching concepts, skills and strategies. New York: The Guilford Press

Fadel, C., Bialink, M. ve Triiling, B. (2015). Four dimensional education: The competencies learners need to succeed. Center for Curriculum Redesign. Erişim adresi: http://curriculumredesign.org/ourwork/four-dimensional-21st-century-education-learning-competencies-future-2030/.

Fauzan, N. (2003). The effects of metacognitive strategies on reading comprehension: A quantitative synthesis and empirical investigation (Doctoral dissertation), Durham University, England. Erişim adresi: http://etheses.dur.ac.uk/1086/1/1086.pdf.

Flavell, J.H., Green, F.L. ve Flavell, E.R. (1993). Chilrens's understanding of consciousness. Child Development, 64(2), 387-398.

Fountas, I.C. ve Pinnell, G. S. (2006). Teaching for comprehending and fluency: Thinking, talking and writing about reading $K-8$. Portsmouth: Heinemann.

Hartman, H.J. (2002). Developing students metacognitive knowledge and skills. H. J. Hartman (Ed.), Metacognition in learning and instruction: Theory, research and instruction (ss. 33-69). NY: Springer-Science+Business Media.

Hattie, J., Biggs, J. ve Purdie, N. (1996). Effects of learning skills interventions on student learning: A meta-analysis. Review of Educational Research, 66(2), 99-136.

Hodges, G.C. (2011). Textual drama: The value of reading aloud. English Drama Media, 19, 19-26.

Israel, S.E. (2007). Using metacognitive assesments to create individualized reading instruction. USA: International Reading Association.

Jacobs, J.E. ve Paris, S.G. (1987). Children's metacognition about reading: Issues in definition, measurement, and instruction. Educational Psychologist, 22, 255-278. 
Jairam, D., Kiewra, K.A., Rogers-Kasson, S., Patterson-Hazley, M. ve Marxhausen, K. (2013). SOAR versus SQ3R: a test of two study systems. Instructional Science. Erişim adresi: https://doi: 10.1007/s11251-013-9295-0.

Johnstone, V. (2015). The power of the read aloud in the age of common core. The Open Communication Journal, 9, 34-38.

Karasar, N. (2012). Bilimsel araştırma yöntemi. Ankara: Nobel Yayıncılık.

Kistner, S., Rakoczy, K., Otto, B., Dignath-van Ewijk, C., Buettner, G. ve Klieme, E. (2010). Promotion of self-regulated learning in classrooms: investigating frequency, quality, and consequences for student performance. Metacognition and Learning, 5(2), 157-171. Erişim adresi: https://doi.org/(...)07/s11409-010-9055-3.

Kistner, S., Rakoczy, K., Otto, B. ve Klieme, E. (2015). Teaching learning strategies: The role of instructional context and teacher beliefs. Journal of Educational Research Online, 7(1), 176197.

Kuhn, D. (2000). Metacognitive development. Current Directions in Psychological Science, 9, 178-181.

Leech, N. L. ve Onwuegbuzie, A. J. (2009). A typology of mixed methods research designs. Qual Quant, 43, 265-275.

Lesesne, T.S. (2006). Reading aloud: A worthwile investment?. Voices From The Middle, 13(4), 50-54.

Lin, X. (2001). Designing metacognitive activities. ETR\&D, 49(2), 23-40.

Milî̂ Eğitim Bakanlığı (2019). PISA 2018 ulusal ön raporu (Eğitim Analiz ve Değerlendirme Raporları Serisi No. 10). Ankara: Millî Eğitim Bakanlığı. Erişim adresi: http://pisa.meb.gov.tr/wpcontent/uploads/2020/01/PISA_2018_Turkiye_On_Raporu.pdf.

Mokhtari, K. ve Reichard, C.A. (2002). Assessing students' metacognitive awareness of reading strategies. Journal of Educational Psychology, 94(2), 249-259.

Nietfeld, J.L. ve Schraw, G. (2002). The effect of knowledge and strategy training on monitoring accuracy. The Journal of Educational Research, 95(3), 131-142.

Nokes, J. D. ve Dole, J. A. (2004). Helping adolescent readers through explicit strategy instruction. T. J. Letton ve J. A. Dole (Eds.). Adolescent literacy research and practice (ss. 162-182). New York: Guilford Press.

Öztürk, E. (2012). Okuma stratejileri üstbilişsel farkındalık envanterinin Türkçe formunun geçerlik ve güvenirlik çalışması. Illköğretim Online, 12(2), 292-305.

Paris, S. G. ve Myers, M. (1981). Comprehension monitoring, memory, study strategies of good, and poor readers. Journal of Reading Behavior, XIII(1), 5-22.

Pauk, W. (1984). The new SQ4R. Reading World, 23(3), 274-275.

Peteranetz, M. S. (2014). Fostering metacognition in the middle school classroom: An exploration of teachers' practice (Master of Arts Thesis). Collage of Education and Human Sciences, University of Nebraska, Lincoln.

Pintrich, P. R. (2002). The role of metacognitive knowledge in learning, teaching, and assessing. Theory Into Practice, 41(4), 219-225.

Pressley, M. (2002). Metacognition and self-regulated comprehension. A. E. Fartsrup ve S. J. Samuels (Eds.), What research has to say about reading instruction (ss. 291-310). USA: International Reading Association.

Rahman, F. ve Mahsur, R. (2011). Is metacognition a single variable?. International Journal of Business and Social Science, 2(5), 135-141.

Randi, J. ve Corno, L. (2000). Teacher innovations in self-regulated learning. M. Boekaerts, P. R. Pintrich ve M. Zeidner (Eds.), Handbook of self-regulation (ss. 651-683). New York: Academic Press.

Robb, L. (2007). Model reading strategies to improve comprehension for all students. Adolescent Literacy In Perspective. Erişim adresi: http://www.teachhub.com/model-reading-strategiesimprove-comprehension-all-students.

Rosenshine, B. (1987). Explicit teaching and teacher training. Journal of Teacher Education, 38(3), 3436.

Schraw, G. ve Moshman, D. (1995). Metacognitive theories. Educational Psychological Review, 7, 351371. 
Schreiber, F.J. (2005). Metacognition and self-regulation in literacy. S.E. Israel, C.C. Block, K.L. Bauserman ve K.K. Welsch (Eds.), Metacognition in literacy learning. Theory, assessment, instruction and professional development (ss. 215-241). New Jersey: LEA Publishers.

Serafini, F. ve Giorgis, C. (2003). 13 good reasons to read aloud with older students. F. Serafini ve C. Giorgis (Ed.), Reading aloud and beyond (ss. 6-12). Portsmouth, NH: Heinemann.

Simpson, M. L. ve Nist, S. L. (2000). An update on strategic learning: It's more than textbook reading strategies. Journal of Adolescent and Adult Literacy, 43(6), 528-541.

Teddlie, C. ve Yu, F. (2007). Mixed methods sampling: A typology with examples. Journal of Mixed Methods Research, 1(1), 77-100. Erişim adresi: https://doi.org/10.1177\%2F1558689806292430

Tetik, N., Zorlu, N., Türker, H. ve Polat, Z. (2016). Ortaokul öğretmen kılavuz kitabı. Türkçe 5. sınıf. Ankara: Millî Eğitim Bakanlığı Yayınları.

U.S. Department of Education, Office of Vocational and Adult Education. (2012). TEAL Just write! Guide (Contract No. ED-VAE-09-0-0060). Washington, DC: Author. Erişim adresi: https://lincs.ed.gov/sites/default/files/TEAL_JustWriteGuide.pdf.

Van der Broek, P. ve Kremer, K. E. (2000). The mind in action: What it means to comprehend during reading. B. M. Taylor, M. F. Graves ve P. Van der Broek (Eds.), Reading for meaning: Fostering comprehension in the middle grades (ss. 1-32). New York: Teachers College Press.

Veenman, M.V.J., Van Hout-Wolters, B.H.A.M. ve Afflerbach, P. (2006). Metacognition and learning: Conceptual and methodological considerations. Metacognition Learning, 1, 3-14.

Wong, L. (2012). Learning from collage textbooks, effective study skills. USA: Wadsworth, Cengage Learning.

Yıldırım, A. ve Şimşek, H. (2013). Sosyal bilimlerde nitel araştırma yöntemleri (9. bs.). Ankara: Seçkin Yayıncılık.

Zimmerman, B. J. ve Moylan, A. R. (2009). Where metacognition and motivation Intersect. D. J. Hacker, J. Dunlosky ve A. C. Graesser (Eds.), Handbook of metacognition. New York: Routledge.

\section{Introduction}

\section{Extended Abstract}

Metacognitive awareness refers to the awareness of one's own thinking, understanding, or learning process and regulating it. It has been observed that metacognitive awareness skills can be taught to improve students' learning skills. In this respect, teachers need to develop students' metacognitive awareness skills through planned classroom practices.

Teachers generally use "implicit" and "explicit" approaches to develop students' metacognitive awareness in classes. The implicit approach is adopted in holistic reading programs. It is thought that students develop concepts through their mental interactions and actions through implicit instruction, in which the constructivist approach is adopted. In this approach, students are active individuals who form concepts inductively. They evaluate what they read and hear as a whole in its own context, and determine the learning path that is suitable for them (Schreiber, 2005). Explicit strategy teaching approach that allows teachers to explain, model, and give feedback about reading strategies was adopted in this study which aimed to examine the relationship between different teaching approaches and students' reading strategies and cognitive awareness skills. In the experimental groups, two different strategy teaching approaches were adopted in which the teacher acted as the "guide" in the first experimental group and as a "model" who explained the strategies in the second experimental group. Strategy teaching in the experimental groups was carried out using holistic reading strategies. In the control group, strategies were taught independently and with an implicit approach under the guidance of the teacher. This study aimed to answer the following research questions:

1. Is there a significant difference between the reading strategies and metacognitive awareness levels of the students in the experimental groups 1 and 2 in which the teaching of reading strategies was done and the students in the control group?

2. What are the opinions of the students in the experimental groups 1 and 2 about the general reading strategies? 
3. What are the opinions of the students in the experimental groups 1 and 2 about the problem-solving strategies?

4. What are the opinions of the students in the experimental groups 1 and 2 about the strategies that support reading strategies?

\section{Method}

The study has the partially mixed order dominant status design. The study groups were formed using criterion sampling. In the experimental phase, 95 students participated while 32 students participated in the qualitative phase. The study lasted 10 weeks. The "Metacognitive Awareness of Reading Strategies Inventory" (MARSI) and a semi-structured interview form were used as the data collection tools. SPSS v. 22 was used for the analysis of the quantitative data, and MAXQDA 12 software was used in qualitative data analysis.

\section{Result and Discussion}

When the results of the students in the experimental groups were compared with those of the students in the control group, significant differences were observed in favor of the students in the experimental groups in terms of supporting reading strategies, problem-solving, general reading strategies, and overall metacognitive awareness. There was no difference between the experimental groups 1 and 2. No significant difference was observed in the metacognitive awareness of reading strategies levels of the students in the control group in which reading lessons were conducted per the Turkish Course Curriculum. This may have stemmed from the fact that the current curriculum adopts an implicit approach and teaches strategies independently.

In the light of this finding, it can be said that the explicit strategy teaching approach was effective primarily in the experimental groups and the implicit strategy teaching approach was effective in the control group. Although no significant difference was observed in the quantitative results, the qualitative results showed that metacognitive awareness of reading strategies were used more in the experimental group 2 in which the teacher acted as the model and explained the strategies compared with the students in the experimental group 1 in which the teacher guided the SQ4R strategy. In other words, it can be said that the teaching approach employed was effective in developing the students' reading strategies and metacognitive awareness.

SQ4R in the experimental group 1 and interactive reading aloud (IRA) holistic reading strategies were used in the experimental group 2, in which the explicit strategy teaching approach was adopted. Holistic reading strategies are strategies that present the strategies that should be used before, during, and after reading for a specific reading task in a connected way. Using the strategies holistically ensures effective learning by helping students to memorize and organize newly learned information. These strategies improve students' ability to understand new information, increase their concentration, provide active learning, and thus improve their metacognitive awareness. Hattie et al. (1996) state that more positive and effective results may be obtained when strategies contribute to metacognitive awareness and self-regulation skills in certain contexts instead of generalized skills in strategy education. In this respect, it can be said that the SQ4R and IRA holistic reading strategies used in the experimental groups contributed to the development of the metacognitive awareness skills of the students.

Considering the 2018 Turkish Course Curriculum, which aims to educate individuals who learn to learn, it may be said that it is important to plan strategy instruction, methods, and techniques to be used in addition to the teacher's teaching approach to educate their students to become life-long learners with advanced metacognitive awareness skills. 